\title{
Roles of Cbln1 in Non-Motor Functions of Mice
}

\author{
(DShintaro Otsuka, ${ }^{1,2 *}$ Kohtarou Konno, ${ }^{2,3 *}$ Manabu Abe, ${ }^{2,4}$ Junko Motohashi, ${ }^{1,2}$ Kazuhisa Kohda, ${ }^{1,2}$ Kenji Sakimura, ${ }^{2,4}$ \\ Dasahiko Watanabe, ${ }^{2,3}$ and (Dichisuke Yuzaki ${ }^{1,2}$ \\ ${ }^{1}$ Department of Physiology, Keio University School of Medicine, Tokyo 160-8582, Japan, ${ }^{2}$ Core Research for Evolutional Science and Technology, Japan \\ Science and Technology Corporation, Saitama 332-0012, Japan, ${ }^{3}$ Department of Anatomy, Hokkaido University Graduate School of Medicine, Sapporo \\ 060-8638, Japan, and ${ }^{4}$ Department of Cellular Neurobiology, Brain Research Institute, Niigata University, Niigata 951-8585, Japan
}

The cerebellum is thought to be involved in cognitive functions in addition to its well established role in motor coordination and motor learning in humans. Cerebellin 1 (Cbln1) is predominantly expressed in cerebellar granule cells and plays a crucial role in the formation and function of parallel fiber-Purkinje cell synapses. Although genes encoding Cbln1 and its postsynaptic receptor, the delta2 glutamate receptor (GluD2), are suggested to be associated with autistic-like traits and many psychiatric disorders, whether such cognitive impairments are caused by cerebellar dysfunction remains unclear. In the present study, we investigated whether and how Cbln1 signaling is involved in non-motor functions in adult mice. We show that acquisition and retention/retrieval of cued and contextual fear memory were impaired in $C b \ln 1$-null mice. In situ hybridization and immunohistochemical analyses revealed that Cbln1 is expressed in various extracerebellar regions, including the retrosplenial granular cortex and the hippocampus. In the hippocampus, Cbln 1 immunoreactivity was present at the molecular layer of the dentate gyrus and the stratum lacunosum-moleculare without overt mRNA expression, suggesting that Cbln1 is provided by perforant path fibers. Retention/retrieval, but not acquisition, of cued and contextual fear memory was impaired in forebrain-predominant Cbln1-null mice. Spatial learning in the radial arm water maze was also abrogated. In contrast, acquisition of fear memory was affected in cerebellum-predominant $C b \ln 1$-null mice. These results indicate that Cbln1 in the forebrain and cerebellum mediates specific aspects of fear conditioning and spatial memory differentially and that Cbln 1 signaling likely regulates motor and non-motor functions in multiple brain regions.

Key words: cerebellum; fear conditioning; hippocampus; retrosplenial granular cortex; synapse formation

\section{Significance Statement}

Despites its well known role in motor coordination and motor learning, whether and how the cerebellum is involved in cognitive functions remains less clear. Cerebellin $1(\mathrm{Cb} \ln 1)$ is highly expressed in the cerebellum and serves as an essential synaptic organizer. Although genes encoding Cbln 1 and its receptor are associated with many psychiatric disorders, it remains unknown whether such cognitive impairments are caused by cerebellar dysfunction. Here, we show that Cbln1 is also expressed in the forebrain, including the hippocampus and retrosplenial granular cortex. Using forebrain- and cerebellum-predominant conditional Cbln1-null mice, we show that Cbln1 in the forebrain and cerebellum mediates specific aspects of fear conditioning and spatial memory differentially, indicating that Cbln1 signaling regulates both motor and non-motor functions in multiple brain regions.

\section{Introduction}

The cerebellum regulates motor coordination and motor learning in humans and experimental animals (Ito, 2001). Several lines

\footnotetext{
Received Jan. 29, 2016; revised Sept. 23, 2016; accepted 0ct. 10, 2016.

Author contributions:S.O., K. Konno, K. Kohda, K.S., M.W., and M.Y. designed research; S.O., K. Konno, M.A., J.M., and K. Kohda performed research; M.A., K.S., and M.W. contributed unpublished reagents/analytic tools; S.O., K. Konno, K. Kohda, M.W., and M.Y. analyzed data; S.O. and M.Y. wrote the paper.

This work was supported by the Japan Science and Technology Corporation [Core Research for Evolutional Science and Technology (CREST) grant to M.Y.], the Ministry of Education, Culture, Sports, Science and Technology (MEXT) of Japan (Grants-in-Aid 15H05772 and 16H06461 to M.Y.), the Keio Gijuku Fukuzawa Memorial Fund for the Advancement of Education and Research (S.0.), the Sumitomo Foundation (Grant for Basic Science Research Projects 141036 to K.K.), and the Takeda Science Foundation (M.Y.). We thank S. Narumi for technical assistance.

The authors declare no competing financial interests.
}

of evidence have indicated that the cerebellum is also involved in cognitive functions (Strata et al., 2011; Reeber et al., 2013). Viral tracing and functional imaging studies in human and nonhuman primates have shown that cerebellar output is functionally connected with vast regions of the non-motor neocortex, such as the prefrontal and posterior parietal cortices (Stoodley and Schmahmann, 2010; Buckner et al., 2011; Bostan et al., 2013). Further-

\section{*S.O. and K.K. contributed equally to this work.}

Correspondence should be addressed to Michisuke Yuzaki, Department of Physiology, Keio University School of Medicine, 35 Shinanomachi, Shinjuku-ku, Tokyo 160-8582, Japan. E-mail: myuzaki@a5.keio.jp.

DOI:10.1523/JNEUROSCI.0322-16.2016

Copyright $\odot 2016$ the authors $\quad 0270-6474 / 16 / 3611801-16 \$ 15.00 / 0$ 
more, various spontaneous cerebellar mutant mice had increased distance in the hidden, but not in the visible, platform version of the Morris water maze, indicating a deficit in spatial orientation (Lalonde and Strazielle, 2003). Similarly, mice that specifically expressed protein kinase C inhibitor in Purkinje cells (L7-PKCI) displayed poor performance in the hidden-platform Morris water maze (Burguière et al., 2005). Indeed, place cell properties in the hippocampus were impaired exclusively when L7-PKCI mice relied on self-motion cues in the water maze (Rochefort et al., 2011). Purkinje cell-specific deletion of $t s c 1$, a gene responsible for tuberous sclerosis, caused autism-like behaviors such as impaired social interaction and repetitive behavior in mice without severely affecting motor functions (Tsai et al., 2012). Conversely, L7-PKCI mice and three other cerebellum-specific mutants showed normal social interaction, spatial orientation in the Morris water maze, and fear conditioning (Galliano et al., 2013). Therefore, whether the cerebellum plays a major role in nonmotor functions in mice has remained unclear.

Cerebellin $1(\mathrm{Cb} \ln 1)$ is expressed predominantly in cerebellar granule cells (Hirai et al., 2005). It is released from parallel fibers (PFs; axons of granule cells) and binds to its postsynaptic receptor, glutamate receptor delta2 (GluD2) (Matsuda et al., 2010). Cbln1-GluD2 signaling plays a crucial role at PF-Purkinje cell synapses; mice lacking Cbln1 or GluD2 displayed impaired motor coordination and motor learning (Matsuda et al., 2010; Emi et al., 2013). Interestingly, a genome-wide association study of autistic-like traits in a general population implicated the CBLN1 gene in the risk of clinical autism spectrum disorder (ASD) (Jones et al., 2013). In addition, copy number variations in the GRID2 gene encoding GluD2 are reported in ASD patients (Gazzellone et al., 2014; Pinto et al., 2014). Furthermore, several human cases of de novo (Maier et al., 2014) and inherited (Hills et al., 2013; Utine et al., 2013) mutations in GRID2 displayed, not only cerebellar ataxia, but also cognitive impairment. Whether such cognitive impairments were caused by cerebellar dysfunctions has remained unclear because both Cbln 1 and GluD2 mRNAs are also expressed outside of the cerebellum, albeit at much lower levels (Miura et al., 2006; Hepp et al., 2015; Konno et al., 2014).

In this study, to clarify whether and how Cbln1 signaling is involved in non-motor functions, we examined fear conditioning in forebrain (FB)- and cerebellum-predominant (CB)-Cbln1null mice. We showed that Cbln 1 in the forebrain and cerebellum mediates specific aspects of fear conditioning and spatial memory differentially, indicating that Cbln 1 signaling regulates both motor and non-motor functions in multiple brain regions.

\section{Materials and Methods}

Procedures. All procedures relating to animal care and treatment were performed according to the guidelines set by the Animal Resource Committee of Keio University. The animals were killed by decapitation after anesthetization with pentobarbital (Kyoritsu Seiyaku).

Animals. Cbln1-null mice were generated as described previously (Hirai et al., 2005) and backcrossed to C57BL/6J mice (Charles River Laboratories) for more than eight generations. Conditional Cbln1-null mice (Cbln1 $1^{\text {flox/flox; }}$ RRID:MGI:5796291) were generated as follows. A genomic clone, RP23-aaaYxx, containing the Cbln1 gene was isolated from a C57BL/6 BAC genomic library (Advanced GenoTechs). A 0.65-kb DNA fragment carrying a part of exon 3 was amplified by PCR and inserted into the SacI sites of middle entry clone (pDME-1). In this clone, a DNA fragment of loxP sequence and pgk promoter-driven neomycinresistant gene-p(A) (neocassette) flanked by two frt sites was located at the site 187 bp upstream of exon 3 , whereas the other loxP sequence was placed at the site $164 \mathrm{bp}$ downstream of the stop codon in exon 3 of the Cbln1 gene. The 5.95-kb upstream and 7.74-kb downstream homolo- gous genomic DNA fragments were retrieved from the BAC clone by using Quick and Easy BAC modification Kit (Gene Bridges) and then subcloned to the $5^{\prime}$ entry clone (pD5UE-2) and $3^{\prime}$ entry clone (pD3DE2 ), respectively. For targeting vector assembly, the three entry clones were recombined to the destination vector plasmid (pDEST-DT) containing an MC1 promoter-driven diphtheria toxin gene using the MultiSite Gateway Three-fragment Vector Construction Kit (Thermo Fisher Scientific).

The culture of embryonic stem (ES) cells and the generation of chimeric mice were performed as described previously (Kakegawa et al., 2015). Briefly, linearized targeting vector plasmids were introduced into the C57BL/6N mouse ES line (RENKA) and then G418-resistant clones were picked up. Homologous recombinant ES clones were identified with Southern blot analysis. To generate germline chimera, the cells were microinjected into eight-cell-stage embryos of the CD-1 mouse strain. The embryos were cultured to the blastocyst stage and transferred to a pseudopregnant CD-1 mouse uterus. Mouse tail DNA was genotyped by performing PCR with the following specific primers: forward, $5^{\prime}$-AAA CTT CCT ACG TGT TCG TAG-3'; reverse, 5'-GAG AAA CAT TTC ACA TTA CTT CG-3'.

Forebrain- and cerebellum-predominant $C b \ln 1$-null mice were generated by crossing $C b \ln 1^{\text {flox/flox }}$ mice with Camk2a-Cre transgenic mice (Zeng et al., 2001) and Grin2C ${ }^{\text {Cre }}$ knock-in mice (Miyazaki et al., 2012), respectively. Littermates $\left(C b \ln 1^{\text {flox/flox }}\right)$ without the $C r e$ gene were used as controls. The mice were group housed on a 12:12 h light/dark cycle at $22 \pm 1^{\circ} \mathrm{C}$ with food and water available ad libitum.

All behavioral tests were conducted on 1-month-old (26-38 d) or 3- to 5 -month-old mice by an investigator blinded to the mice genotype during the light cycle. After confirming that male and female mice performed similarly in fear conditioning ( $n=9$ for wild-type and $C b \ln 1$-null male mice; data not shown), female mice were used because several mice could be maintained in the same breeding cages without fighting. Mice were moved to the behavioral analysis room and handled once and twice on 2 and $1 \mathrm{~d}$ before each test, respectively.

In situ hybridization. Mouse cDNA fragments of Cbln1 (nucleotides 353-934 bp; GenBank accession \#NM_019626) was subcloned into the pBluescript II plasmid vector. Digoxigenin (DIG)-labeled cRNA probe was transcribed in vitro for chromogenic in situ hybridization (Yamasaki et al., 2010). Fragmentation of riboprobe by alkaline digestion was omitted to increase the sensitivity and specificity. For immunohistochemical detection of DIG, sections were blocked with DIG blocking solution [Tris-NaCl-Tween (TNT) buffer containing 1\% blocking reagent (Roche Diagnostics) and $4 \%$ normal sheep serum] for $30 \mathrm{~min}$. Sections were then incubated with alkaline phosphatase-conjugated sheep anti-DIG (1:1000; Roche Diagnostics) for $1.5 \mathrm{~h}$. After 2 washes with TNT buffer for 15 min each, chromogenic detection was performed using nitroblue tetrazolium and 5-bromo-4-chloro-3' ${ }^{\prime}$-indolyphosphate (1:50; Roche Diagnostics) in detection buffer (0.1 м Tris- $\mathrm{HCl}$, pH 9.5, 0.1 M NaCl, and $50 \mathrm{~mm} \mathrm{MgCl}_{2}$ ) for $12 \mathrm{~h}$. Images were taken with a light microscope (BZ-9000; Keyence).

Immunohistochemistry. For immunohistochemical detection of endogenous Cbln1, mice were deeply anesthetized with intraperitoneal injection of sodium pentobarbital $(200 \mathrm{mg} / \mathrm{kg}$ body weight $)$ and decapitated. The brains were freshly frozen with powdered dry ice and 20 $\mu \mathrm{m}$ sections were made with a cryostat (CM1900; Leica Microsystems). The sections were incubated with $4 \%$ paraformaldehyde for $15 \mathrm{~min}$, followed by $10 \%$ normal donkey serum for $20 \mathrm{~min}$, then with primary antibodies overnight $[1 \mu \mathrm{g} / \mathrm{ml}$ rabbit anti-Cbln1 (RRID:AB_2571672; Miura et al., 2009); guinea pig anti-vesicular glutamate transporter 1 (VGluT1, RRID:AB_2571618; Miyazaki et al., 2003); guinea pig antivesicular GABA transporter (VGAT, RRID:AB_2571624; Fukudome et al., 2004); guinea pig anti-vGluT2 (RRID:AB_2571621; Miyazaki et al., 2003)] overnight, followed by Alexa Fluor 488 (Invitrogen) and Cy3 (Jackson ImmunoResearch)-labeled species-specific secondary antibody (a dilution of 1:200) for $2 \mathrm{~h}$. A confocal laser-scanning microscope (FV1000; Olympus) was used for the analysis.

For comparison of Cbln 1 immunoreactivity in various brain regions, a set of sections from wild-type, Cbln1-null, and FB-Cbln1-null or CB$C b \ln 1$-null mice were immunostained at the same time and images were 
A
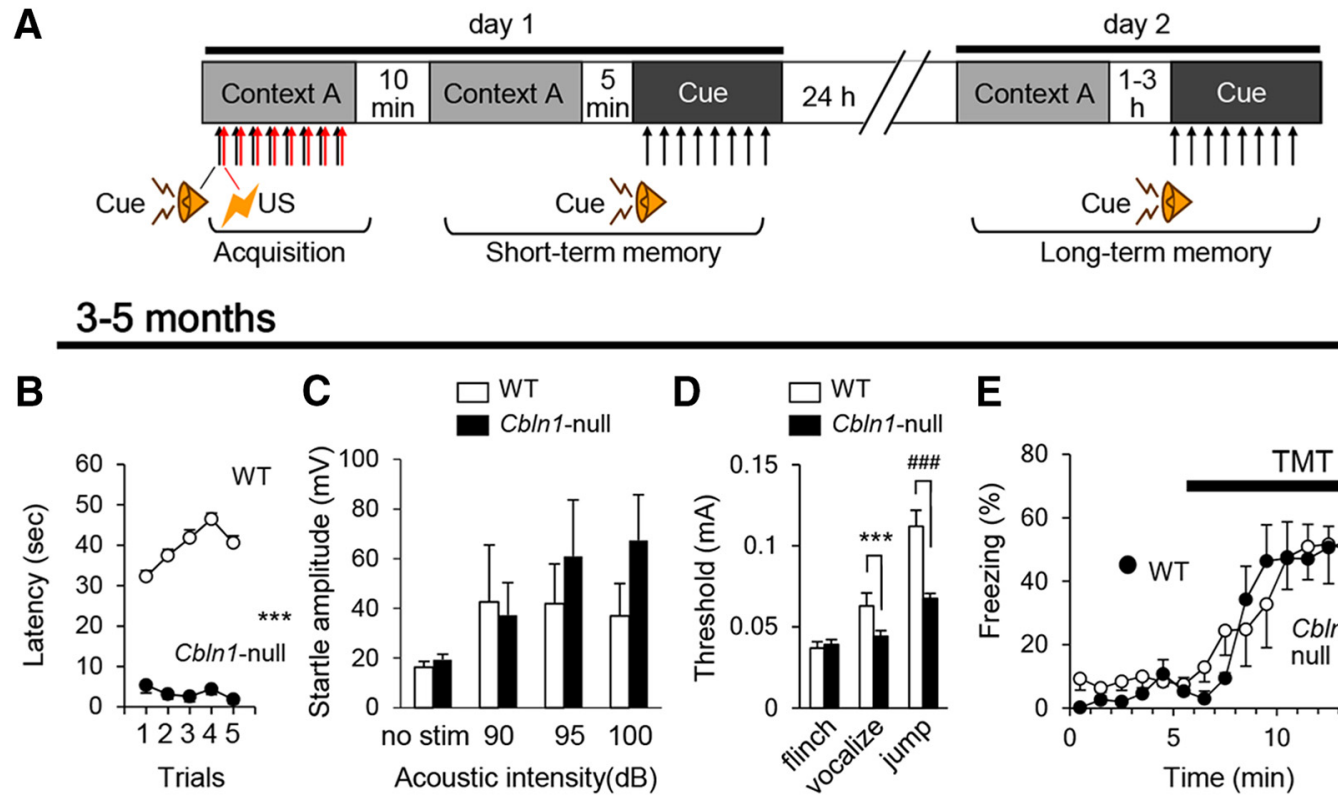

E

F

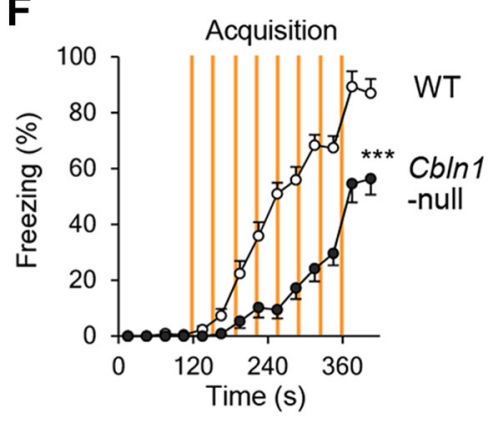

I
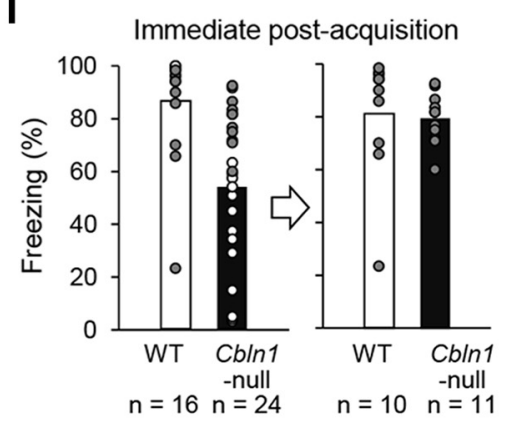

G

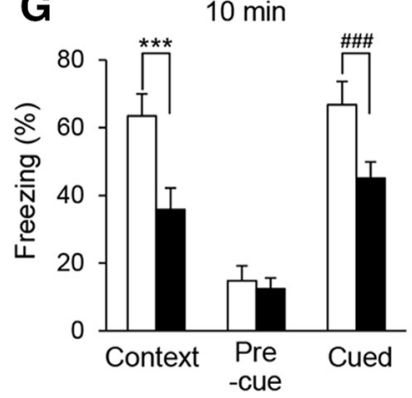

J

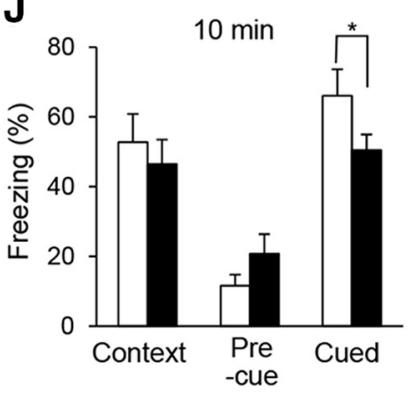

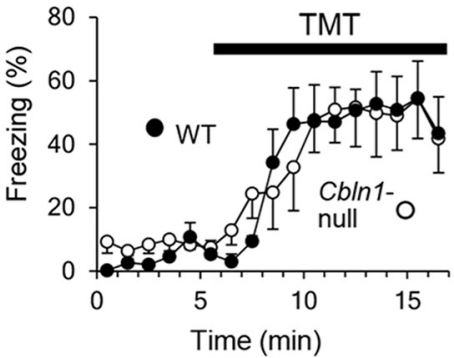

H
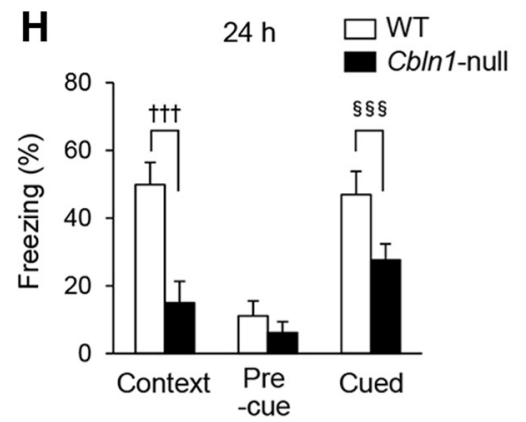

K

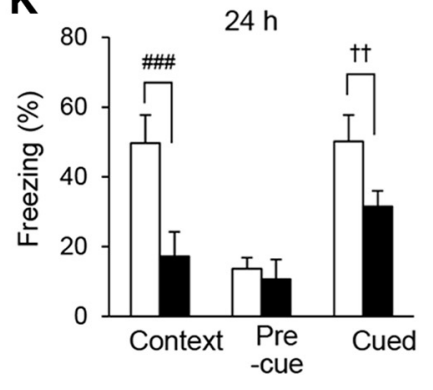

\section{1 month}

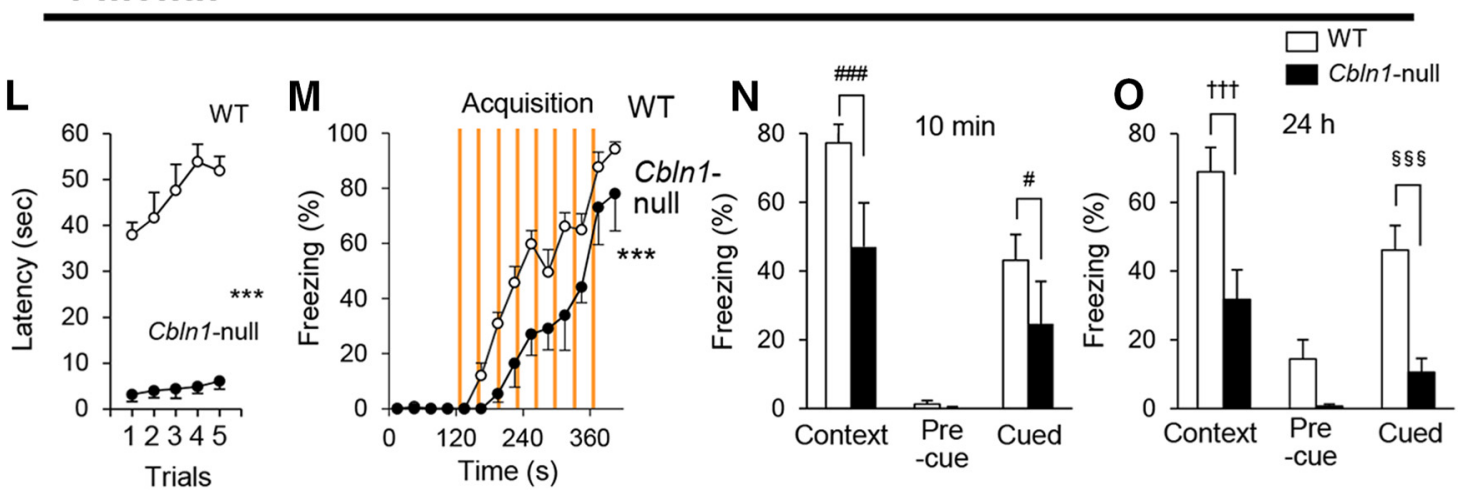

Figure 1. Impaired fear conditioning in (b/n1-null mice. $A$, Schematic representation of the fear conditioning task. On day 1 , mice were placed in context $A$ and received a tone (CS) and a foot shock (US) eight times. At $10 \mathrm{~min}$ and $24 \mathrm{~h}$ after the acquisition, contextual and cued fear memory were assessed in context $A$ without tone and context B with tone, respectively. $B$, Rotarod test in 3- to 5-month-old Cbln1-null (filled circles, $n=11$ ) and wild-type mice (WT; unfilled circles, $n=9$ ). ${ }^{* * *} p=1.43 \times 10^{-9}$. C, Acoustic startle reflex test in 3- to 5-month-old Cbln1-null (filled columns, $n=11)$ and WT ( $n=9)$ mice. D, Pain sensitivity assessed as threshold of electrical currents required to elicit a flinch, vocalization, and a jump. Cbln1-null mice (Figure legend continues.) 
taken with a fixed gain and exposure time. For each brain region, Cbln1 immunoreactivity was averaged from four fields of view from each section and the background immunoreactivity in the corresponding brain region in $C b \ln 1$-null mice was subtracted.

Fear conditioning. Fear-conditioning procedures were performed as described previously (Sacchetti et al., 2004) with minor modifications. For context A, the mice were placed in a transparent chamber with a black ceiling in a soundproof box with white illumination. They were allowed $2 \mathrm{~min}$ for free exploration and then received an auditory tone for $6 \mathrm{~s}(10 \mathrm{kHz}, 60 \mathrm{~dB})$ as a conditional stimulus (CS), which coterminated with a foot shock $(0.75 \mathrm{~mA}$ for $2 \mathrm{~s})$ as an unconditional stimulus (US) 8 times with $30 \mathrm{~s}$ interstimulus intervals. Ninety seconds after the last CS-US presentation, the mice were returned to their home cages. Freezing durations in the last 1 min were measured to evaluate the acquisition of fear conditioning. To test short-term memories, the mice were returned to their home cages for $10 \mathrm{~min}$ and then reexposed to context $\mathrm{A}$ for $2 \mathrm{~min}$ (context test). After another $5 \mathrm{~min}$ of rest in their home cages, they were placed in a novel context (context B), a white chamber with a black-and-white checkerboard pattern ceiling, scattered with fresh animal bedding in a soundproof box with a grapefruit odor and red illumination. The mice were allowed $2 \mathrm{~min}$ for free exploration, and then a series of 8 CS identical to those used during conditioning were applied (cued test). The mice were then returned to their home cages. Twentyfour hours after the conditioning, the context and cued test were performed again to evaluate long-term memory. Freezing was defined as a complete absence of somatic movement except for respiration and was analyzed with the automated freezing analyzing system (Image FZC; O'Hara).

Open-field test. Mice were placed in the corner of the open field $(50 \times$ $50 \times 40 \mathrm{~cm}$ ) lit with 20 lux indirect illumination. Movement of the animals was tracked with the automatic monitoring system (Image OFC; O'Hara $)$ and travel distance and stay duration in the central area $(30 \times 30$ $\mathrm{cm}$ ) were evaluated for $5 \mathrm{~min}$.

Rotarod test. The accelerating rotarod test (MK-670; Muromachi) was performed as described previously (Kakegawa et al., 2015) with minor modification. Briefly, five trials were performed at $0-45 \mathrm{rpm} / 60 \mathrm{~s}$ and a $30 \mathrm{~s}$ interval and the time that each mouse stayed on the rod was measured (maximum score, $120 \mathrm{~s}$ ).

Radial arm water maze test. The radial arm water maze test was conducted as described previously (Alamed et al., 2006) with minor modifications. Black plastic inserts were placed in a water-filled circular tank to

\footnotetext{
(Figure legend continued.) showed lower threshold for eliciting vocalization and jump. ${ }^{* * *} p=7.53 \times 10^{-5} ; \# \# p=4.63 \times 10^{-13}, n=10$ mice for each genotype. $E$, Freezing to TMT, an odor to induce innate fear. TMT was applied from $5 \mathrm{~min}$. No differences were observed between wild-type and $(b / n 1$-null mice in the duration of freezing before and after TMT exposure ( $p=0.981, n=6$ mice for each genotype). $\boldsymbol{F}$, Time course of freezing responses during acquisition of fear memory in adult (3-to 5-month-old) Cbln 1 -null mice. Vertical lines indicate timing of foot shocks. Freezing durations during the acquisition phase $(120-420 \mathrm{~s})$ were significantly reduced in adult Cbln 1 -null mice ${ }^{* * *} p=1.12 \times 10^{-6}$; wild-type, $n=12$, Cbln 1 null, $n=18) . \mathbf{G}, \boldsymbol{H}$, Freezing durations of context- and cue-dependent memory task at $10 \mathrm{~min}$ $(\boldsymbol{G})$ and $24 \mathrm{~h}(\boldsymbol{H})$ after conditioning. Adult $(b / n)$-null mice showed significantly reduced freezing

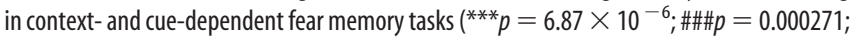
$\mathrm{ttt}, p=6.89 \times 10^{-8} ; \S \S \S p=0.000987$; wild-type, $n=12$, (bln 1 -null, $n=18$ ), but similar baseline freezing responses during the 2 min before exposure to tone in context B (precue). $\boldsymbol{I}-\boldsymbol{K}$, Post hoc analyses of memory retention/retrieval in adult Cbln1-null mice. Subpopulations of wild-type mice that showed less freezing and $(b / n 1$-null mice that showed more freezing were selected arbitrarily so that both groups showed similar levels of acquisition of fear memory (I). The subpopulations of $\mathrm{Cb} / \mathrm{n} 1$-null mice still showed significantly reduced freezing in fear memory tasks $\left({ }^{*} p=0.0188 ; \# \# p=0.00140 \times 10^{-8} ;\right.$ †tp $=0.00575$; wild-type, $n=10$, (bln 1 -null, $n=11$ ) at $10 \mathrm{~min}(\boldsymbol{J})$ and $24 \mathrm{~h}(\boldsymbol{K})$ after conditioning. $\boldsymbol{L}-\mathbf{0}$, Phenotypes of juvenile (1-month-old) Cbln1-null mice. $L$, Juvenile Cbln1-null mice showed shorter latency to fall from rotarod ( ${ }^{* * *} p=1.65 \times 10^{-11}$, wild-type, $n=16$, (bln1-null, $\left.n=10\right)$. $\boldsymbol{M}-\mathbf{0}$, Fear conditioning at 1 month. Acquisition $(M)$ and retention/retrieval of contextual and cued fear memory at $10 \mathrm{~min}(\boldsymbol{N})$ and $24 \mathrm{~h}(\mathbf{0})$ after conditioning were impaired in global Cbln1-null mice at 1 month. ${ }^{* *} p=0.00116$; \#\#p =0.00160; \#p=0.0247; †t+p =0.000229; $\S \S s p=$ 0.0000963; wild-type, $n=9$, Cbln1-null, $n=8$.
}

make six swim paths $(40 \times 20 \mathrm{~cm})$ extending radially from a central area. The inserts were positioned $10 \mathrm{~cm}$ above the water $(10 \mathrm{~cm}$ depth, $24 \pm$ $1^{\circ} \mathrm{C}$ ), which was rendered opaque by adding skim milk. The room was illuminated by indirect light (80 lux) and a number of distinctive extramaze cues (large black stripe and rectangle texture on the wall, door, and a table) were placed in the test room. Each mouse was tested for 15 trials. The goal arm was fixed throughout the test. Visible and invisible platforms were placed alternately in the goal arm during trials 1-12; only the invisible platform was placed during trials $13-15$. The visible platform $(12.5 \times 8 \mathrm{~cm})$ was positioned $2 \mathrm{~mm}$ above the water level and had black-and-white stripes on the top panel. A paper with black-and-white stripes was also attached to the wall of the arm where the visible platform was placed. The invisible platform had the same size but was submerged $1 \mathrm{~cm}$ below the water level; the top panel was also made of transparent plastic. The start (S1-5) arm was randomly chosen from the non-goal arms, which were not adjacent to the previous start arm. Each mouse, facing the center of the pool, was placed gently into the water near the edge of the start arm. Errors were defined when all four limbs of the mice entered the non-goal arms. Goal arm entry without touching the platform was also defined as an error. If the mouse failed to touch or climb onto the platform within $3 \mathrm{~min}$, it was gently guided to the platform. When the mouse climbed onto the platform, it was allowed to stay there for $15 \mathrm{~s}$, followed by towel drying and returning to the home cage under a heat lamp. In this study, eight mice were analyzed at a time. They were divided into two groups, each consisting of two FB-Cbln1-null and two control littermates. All 15 trials were divided into three blocks (block 1, trials 1-6; block 2, trials 7-12; block 3, trials 13-15). Each mouse in a group was tested sequentially. After the preceding group finished one block, the next group started another block while the preceding group was given a rest.

Predator-odor-induced freezing test. Mature Cbln1-null mice and their litter controls were used. Predator-odor-induced fear behavior was analyzed as described previously, with minor modifications (Wallace and Rosen, 2000). Mice were handled twice in a safety cabinet to acclimatize to the environment. A piece of Kimwipe $(1.5 \times 2 \mathrm{~cm})$ was placed on a stainless rod grid (set $9 \mathrm{~mm}$ apart) in a disposable circular test chamber (13 cm in diameter, $10 \mathrm{~cm}$ in height) made of polypropylene. The chamber was placed in a safety cabinet to prevent spreading of the odor during the test. A new chamber was used for each mouse. Each mouse was placed in the test chamber containing no odor for $5 \mathrm{~min}$ to record a baseline level of freezing and then $5 \mu \mathrm{l}$ of 2,5-dihydro-2,4,5-trimethylthiazoline (TMT; Contech), a component of fox feces known to induce innate fear responses in rodents, was applied to the Kimwipe. Freezing behavior was monitored with a CCD camera placed above the test chamber for $12 \mathrm{~min}$ and the tested mouse was returned to a separate home cage to prevent any possible indirect effects on untested mice.

Acoustic startle reflex test. The acoustic startle reflex test (SRLAB; San Diego Instruments) was performed as described previously (Emi et al., 2013). Briefly, after a 5 min acclimation period, the acoustic stimuli (bursts of white noise at $4-14 \mathrm{kHz}$ at three different sound stimuli, 90, 95, and $100 \mathrm{~dB}$, in a random order) were applied to each mouse placed in a Plexiglas cylinder in the presence of a continuous background noise (70 $\mathrm{dB}$ ). The magnitude of the acoustic startle response was measured by the piezoelectric sensor. All trials were repeated nine times.

Data analysis and statistics. All results are presented as the means \pm SEM. Mann-Whitney $U$ test was used for the analysis shown in Figs. 4, $D$ and $E$, and 6, $B$ and $C$. Two-way repeated-measures ANOVA and Bonferroni post hoc test were used for the other analyses unless stated otherwise. All datasets were tested with the Smirnov-Grubbs outlier test with a significance level of 0.05 . Statistical significance was defined as $p<0.05$.

\section{Results}

\section{Impaired cue- and context-dependent fear conditioning in Cbln1-null mice}

To examine non-motor learning in adult wild-type and Cbln1null mice, we used cue- and context-dependent fear conditioning, in which an auditory cue and an environmental context were presented as CS together with an electrical shock as a US (Fig. 
Table 1. Expression of Cbln1 mRNAs in adult mouse brain

\begin{tabular}{|c|c|c|c|}
\hline Region & Signal intensity & Region & Signal intensity \\
\hline Telencephalon & & Dorsal lateral geniculate (DLG) nucleus & - \\
\hline Olfactory bulb (OB) & & Ventral lateral geniculate (VLG) nucleus & - \\
\hline Glomerular layer (GI) & + & Hypothalamus & \\
\hline Mitral layer (Mi) & + & Preoptic nucleus (P0) & + \\
\hline Granular layer (Gro) & - & Lateral area (LH) & + \\
\hline External plexiform layer (EPI) & + & Posterior area $(\mathrm{PH})$ & + \\
\hline External plexiform layer of accessory olfactory bulb (EPIA) & + & Periventricular nucleus (PeV) & - \\
\hline Neocortex (Cx) & & Paraventricular nucleus (PaV) & + \\
\hline Lamina I & - & Dorsomedial nucleus (DM) & + \\
\hline Lamina II/III & - & Ventromedial nucleus (VMH) & + \\
\hline Lamina IV & - & Anterior area (AH) & + \\
\hline Lamina V & - & & \\
\hline Lamina VI & - & Midbrain/pons/medulla & \\
\hline Retrosplenial granular cortex (RSG) layer IV & + & Superior colliculus (SC) & - \\
\hline Claustrum (Cl) & + & Inferior colliculus (IC) & \\
\hline Piriform cortex (Pir) & - & Central nucleus & + \\
\hline Dorsal endopiriform nucleus (DEn) & - & External nucleus (ECIC) & - \\
\hline Entorhinal cortex (Ent) & + & Dorsal nucleus (DCIC) & - \\
\hline Medial (MEnt) & + & Dorsal nucleus of lateral lemniscus (DLL) & - \\
\hline Lateral (LEnt) & + & Parabigeminal nucleus (PBG) & + \\
\hline Hippocampal formation & & Cochlear nuclei & \\
\hline Pyramidal cell & - & Ventral nucleus (VCN) & + \\
\hline Granule cell & - & Dorsal nucleus (DCN) & + \\
\hline Interneuron (Cornu Ammonis) & - & Vestibular nucleus (Ve) & + \\
\hline Interneuron (Dentate gyrus) & + & Trigeminal nucleus & \\
\hline Subiculum & - & Principal sensory nucleus (Pr5) & + \\
\hline Striatum (St) & - & Spinal tract nucleus (Sp5) & + \\
\hline Globus pallidus & - & Oral (Sp50) & + \\
\hline Amygdala & - & Interpolar (Sp5I) & + \\
\hline Septum & & Nucleus of solitary tract (NTS) & - \\
\hline Medial septal nucleus (MS) & - & Dorsal raphe nucleus (DR) & \pm \\
\hline Lateral septal nucleus (LS) & - & Median raphe nucleus (MRN) & + \\
\hline Dorsolateral bed nucleus of stria terminalis (dIBST) & + & Rostral interstitial nucleus of medial longitudinal fasciculus (RI) & + \\
\hline Diencephalon & & Red nucleus (RN) & + \\
\hline Thalamus (Th) & & Pedunculopontine tegmental nucleus (PPTg) & + \\
\hline Anterior nuclear group & & Laterodorsal tegmental $\mathrm{n}$ (LDTg) nucleus & - \\
\hline Anterodorsal nucleus (AD) & \pm & Lateral parabrachial n (LPB) & + \\
\hline Anteroventral nucleus (AV) & + & Medial parabrachial n (MPB) nucleus & + \\
\hline Anteromedial nucleus (AM) & + & Gigantocellular reticular n (Gi) nucleus & + \\
\hline Ventral nuclear group & & Cuneate nucleus (Cu) & + \\
\hline Ventromedial nucleus (VM) & - & Inferior olive (I0) & - \\
\hline Ventral reuniens nucleus (VRe) & + & Dorsal motor $\mathrm{n}(\mathrm{DMN})$ of vagus nerve & + \\
\hline Intralaminar nuclear group & & Hypoglossal nucleus (10) & - \\
\hline Central medial nucleus (CM) & + & Area postrema (AP) & - \\
\hline Parafascicular nucleus (PF) & + & Cerebellum (Cb) & \\
\hline Midline nuclear group & & Purkinje cell layer (PCL) & - \\
\hline Paraventricular nucleus (PV) & - & Granular layer GL) & + \\
\hline Reuniens nucleus (Re) & \pm & Molecular layer (ML) & - \\
\hline Habenular complex & & Cerebellar nuclei (CBN) & + \\
\hline Medial habenular nucleus (MHb) & - & Medial nucleus (Med) & + \\
\hline \multirow[t]{2}{*}{ Lateral habenular nucleus (LHb) } & + & Lateral nucleus (Lat) & + \\
\hline & & Interposed nucleus (Int) & + \\
\hline
\end{tabular}

1A). Conditioned fear memory was evaluated at $10 \mathrm{~min}$ and $24 \mathrm{~h}$ after the acquisition trial by measuring freezing responses to the same context and the cue. Cbln1-null mice were ataxic (Hirai et al., 2005) and could not stay on the rotating rod (Fig. 1B), although they were smaller than wild-type mice (wild-type, $18.2 \pm$ $0.5 \mathrm{~g}, n=9$; Cbln1-null, $14.4 \pm 0.6 \mathrm{~g}, n=11 ; p=0.0001$ by Student's $t$ test). However, as we reported previously (Emi et al., 2013), Cbln1-null mice had normal auditory startle reflex (Fig. $1 C)$ and tail-flick responses to heat. In addition, thresholds of electrical currents that induced flinch, vocalization, or jump were similar or even lower in Cbln1-null mice than in wild-type mice
(Fig. 1D). Furthermore, the duration of freezing induced by TMT, a component of fox feces known to induce innate fear responses in rodents, was not significantly different between wild-type and $C b \ln 1$-null mice (Fig. $1 E$ ). These results indicate that the sensorimotor systems necessary for freezing responses are intact in Cbln1-null mice.

We found that Cbln1-null mice showed significantly lower levels of freezing responses than did wild-type mice during the acquisition period $\left(p=1.12 \times 10^{-6}\right.$; Fig. $\left.1 F\right)$. Similarly, both cue- and context-dependent freezing responses were reduced in Cbln1-null mice at $10 \mathrm{~min}$ (Fig. $1 G$ ) and $24 \mathrm{~h}$ (Fig. $1 \mathrm{H}$ ). To 


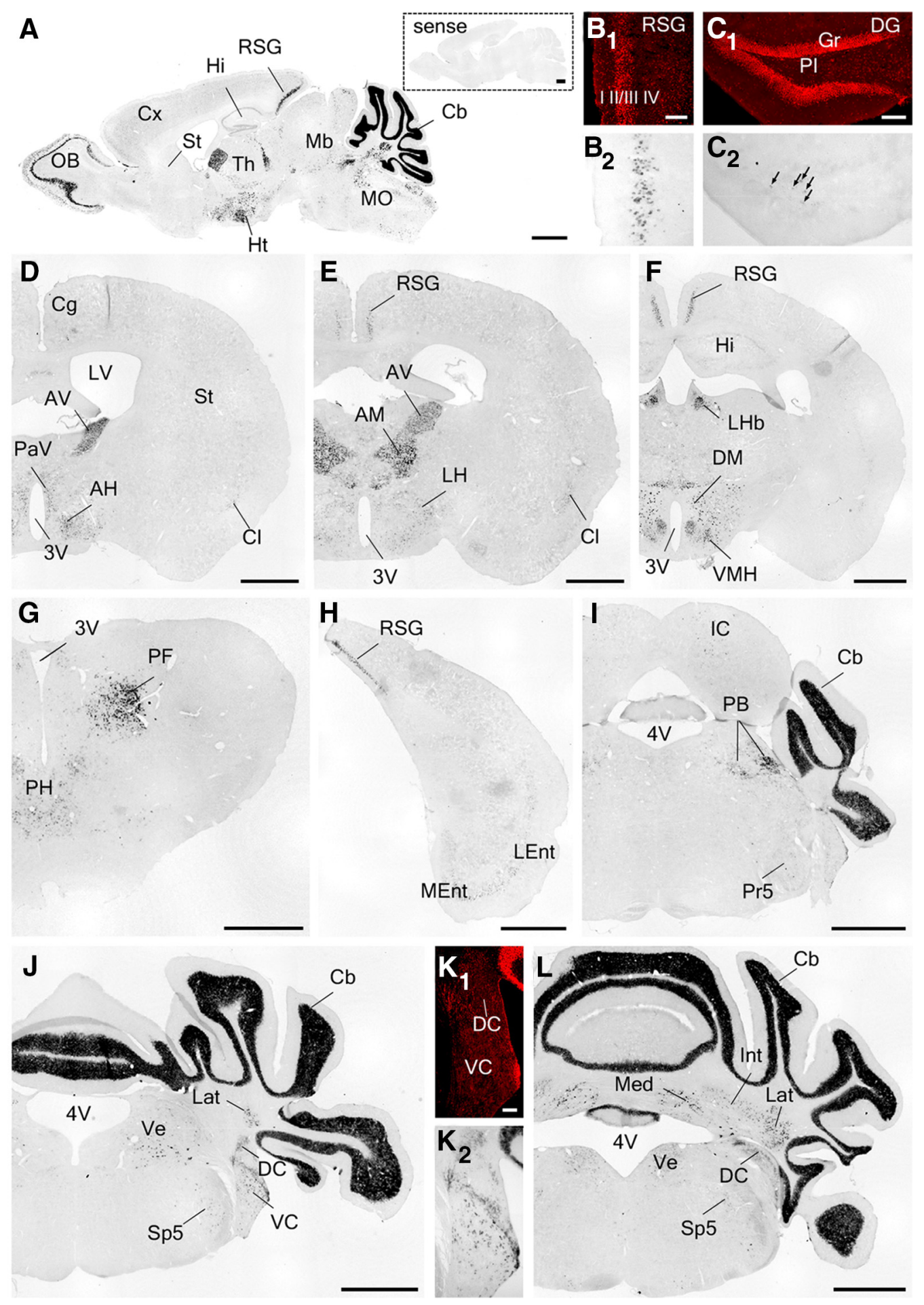

Figure 2. Chromogeneic ISH of Cbln1 mRNA in the adult mouse brain. $\boldsymbol{A}$, Sagittal sections. $\boldsymbol{B}-\boldsymbol{L}$, coronal sections. Hybridization with a sense probe yielded no significant signal ( $\boldsymbol{A}$, inset). Arrows in $C$ indicate interneurons or mossy cells in the dentate gyrus. $3 \mathrm{~V}$, Third ventricle; $4 \mathrm{~V}$, fourth ventricle; $\mathrm{AH}$, anterior hypothalamic area; $\mathrm{AM}$, anteromedial thalamic nucleus; $\mathrm{AV}$, anteroventral thalamic nucleus; $\mathrm{Cb}$, cerebellum; $\mathrm{Cg}$, cingulate cortex; $\mathrm{Cl}$, claustrum; $\mathrm{Cx}$, cortex; $\mathrm{DC}$, dorsal cochlear nucleus; DG, dentate gyrus; DM, dorsomedial hypothalamic nucleus; Gr, granule cell layer; Hi, hippocampus; Ht, hypothalamus; IC, inferior colliculus; Int, interposed cerebellar nucleus; Lat, lateral cerebellar nucleus; LEnt, lateral entorhinal cortex; LH, lateral hypothalamic area; LHb, lateral habenular nucleus; LV, lateral ventricle; Mb, midbrain; Med, medial cerebellar nucleus; $\mathrm{MEnt}$, medial entorhinal cortex; $\mathrm{MO}$, medulla oblongata; $\mathrm{OB}$, olfactory bulb; $\mathrm{PaV}$, paraventricular hypothalamic nucleus; $\mathrm{PB}$, parabrachial nucleus; $\mathrm{PF}$, parafascicular thalamic nucleus; $\mathrm{PH}$, posterior hypothalamic area; Pl, polymorphic cell layer; Pr5, principle sensory nucleus of trigeminal nerve; $\mathrm{RSG}$, retrosplenial granular cortex; Sp5, spinal nucleus of trigeminal nucleus; St, striatum; Th, thalamus; VC, ventral cochlear nucleus; Ve, vestibular nucleus; VMH, ventromedial hypothalamic nucleus. Scale bars: $A, D-J, L, 1 \mathrm{~mm} ; \boldsymbol{B}, C, K, 100 \mu \mathrm{m}$.

determine whether these memory defects were caused by impaired acquisition in Cbln1-null mice, we performed post hoc analyses of a subpopulation of Cbln1-null mice that displayed freezing responses to a level similar to that of wild-type mice immediately after the acquisition period (Fig. 1I). Although these Cbln1-null mice showed levels of context-dependent freezing responses similar to those shown by wild-type mice at $10 \mathrm{~min}$ after the conditioning (Fig. 1J), they displayed reduced cue- and 

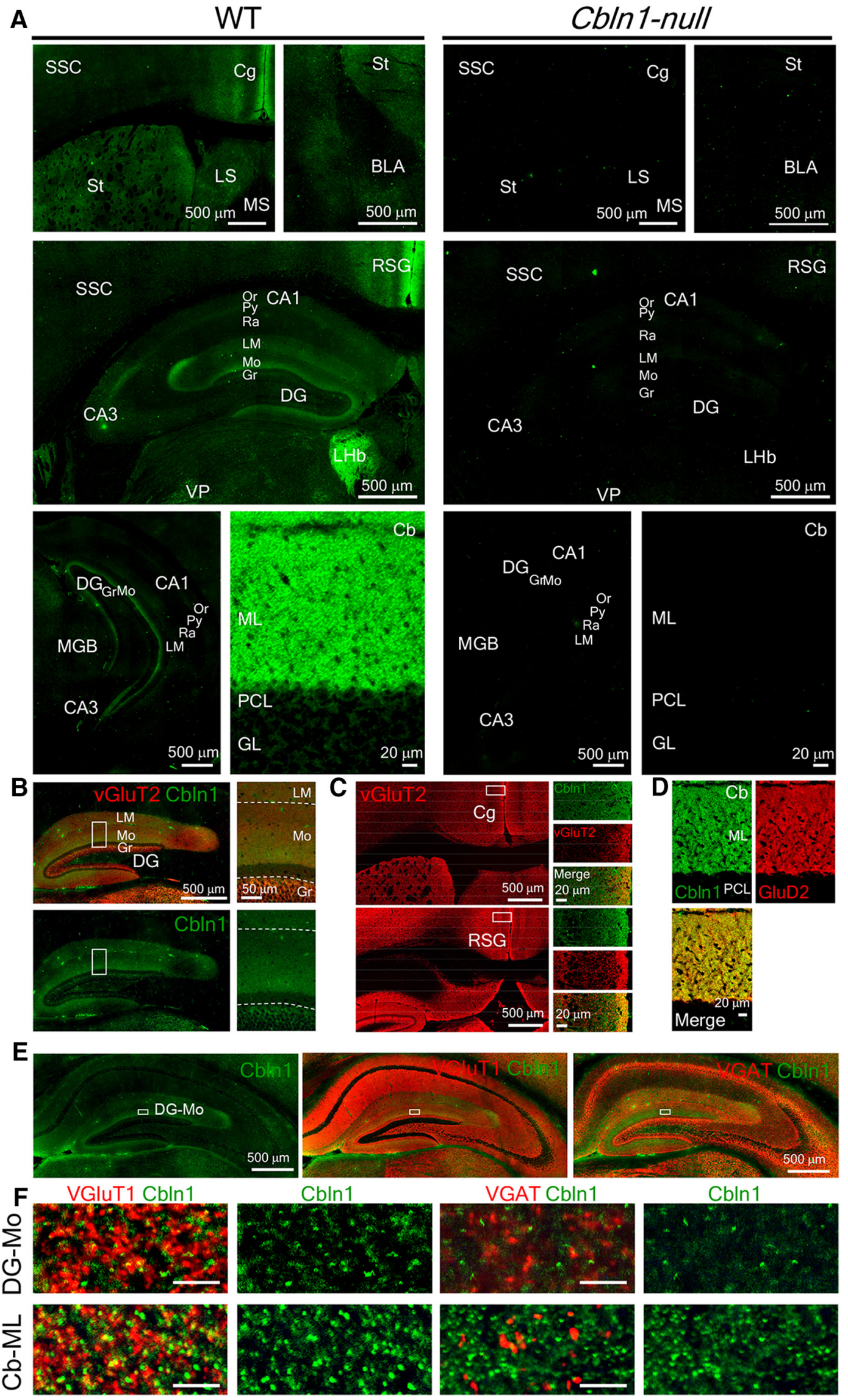

Figure 3. Cbln1 expression in the forebrain. $A$, Immunohistochemical analyses revealed Cbln1 expression in distinct brain regions, including the stratum lacunosum-moleculare (LM) and molecular layer (Mo) of the hippocampus, Cg, and RSG. Right, Cbln1 immunoreactivities in Cbln1-null mice. BLA, Basolateral amygdala; Cb, cerebellum; GL, (Figure legend continues.) 
context-dependent freezing responses at $24 \mathrm{~h}$ (Fig. $1 \mathrm{~K}$ ). Together, these results indicate that, not only acquisition of fear conditioning, but also long-term memory retention and/or retrieval is impaired in adult $C b \ln 1$-null mice.

Interestingly, Cbln1-null mice not only moved shorter distances (wild-type, $13 \pm 2 \mathrm{~m}, n=10$; Cbln1-null, $8 \pm 1 \mathrm{~m}, n=11$; $p=0.03$ by Student's $t$ test), but also stayed for longer durations at the center (wild-type, $9 \pm 4 \%, n=10$; Cbln1-null, $24 \pm 6 \%$, $n=11 ; p=0.0465$ by Student's $t$ test) in the open-field test. These results indicate that adult $C b \ln 1$-null mice exhibit lower basal anxiety levels.

To examine the roles of Cbln1 in the forebrain and the cerebellum in the following studies, we used Cre recombinase under region-specific promoters. Because the brain regions affected by these promoters depended on the developmental stage, we examined phenotypes of Cbln1-null mice at 1 month as a control. Cbln1-null mice could not stay on the rotating rod even at 1 month (Fig. $1 L)$. In the open-field test, $C b \ln 1$-null mice also showed lower activities (wild-type, $15 \pm 1 \mathrm{~m}, n=18$; Cbln1-null, $6.0 \pm 0.6 \mathrm{~m}, n=10 ; p=4.77 \times 10^{-6}$ by Student's $t$ test), but stayed at the center for durations similar to wild-type mice (wildtype, $6 \pm 1 \%, n=18$; Cbln1-null, $5 \pm 3 \%, n=10 ; p=0.579$ by Student's $t$ test). Importantly, juvenile $C b \ln 1$-null mice not only showed impaired freezing responses during the acquisition period (Fig. $1 \mathrm{M}$ ), but also at $10 \mathrm{~min}$ (Fig. $1 \mathrm{~N}$ ) and $24 \mathrm{~h}$ (Fig. 1O) after the conditioning in cue- and context-dependent tests. These results indicate that Cbln 1 is required for fear conditioning as early as at 1 month of age.

\section{Cbln1 expression in the forebrain}

Cbln $1 \mathrm{mRNAs}$ were reported to be expressed in certain forebrain regions, albeit at much lower levels than in the cerebellum (Miura et al., 2006). To clarify whether and how Cbln1 outside the cerebellum is involved in non-motor learning, we first performed highly sensitive chromogenic in situ hybridization (ISH) by using a long antisense riboprobe (Table 1). We found that Cbln 1 mRNA was expressed in certain regions in the telencephalon, including layer IV of the retrosplenial granular cortex (RSG; Fig. $2 A, B, E, F, H$ ), the claustrum (Fig. $2 D, E$ ), and the entorhinal cortex (Fig. $2 H$ ); the signal was absent from the cingulate cortex $(\mathrm{Cg}$; Fig. 2D), the amygdala, and hippocampal formation, except for low signals in interneurons or mossy cells in the dentate gyrus (Fig. 2C). Cbln1 mRNA was also detected in the anteroventral, anteromedial, and parafascicular nuclei of the thalamus, the lateral habenular nucleus (LHb), and several nuclei in the hypothalamus (Fig. 2D-G). Cbln 1 mRNA was also expressed in various nuclei in the hindbrain, such as the parabrachial nucleus (Fig. $2 I$ ), trigeminal nucleus (Fig. $2 I$ ), vestibular nucleus (Fig. 2J, $L$ ), cochlear nuclei (Fig. $2 K$ ), and cerebellar nuclei (Fig. $2 L$ ). Speci-

\footnotetext{
$\leftarrow$

(Figure legend continued.) granular layer of the cerebellum; $\mathrm{Gr}$, granular cell layer; $\mathrm{LHb}$, lateral habenula; $L S$, Lateral septum; MGB, medial geniculate body; ML, molecular layer of the cerebellum; Or, stratum oriens; PCL, Purkinje cell layer; Py, pyramidal cell layer; Ra, stratum radiatum; SSC, somatosensory cortex; St, striatum; VP, ventral posterior nucleus of the thalamus. Scale bars, $20 \mu \mathrm{m}$ for the cerebellum and $500 \mu \mathrm{m}$ for the rest of the panels. B, C, Immunoreactivity of Cbln1 (green) and VGluT2 (red) in the hippocampus (B) and the C $g$ and RSG (C). $\boldsymbol{D}$, Immunoreactivity of $\mathrm{Cbln} 1$ (green) and GluD2 (red) in the cerebellum. $\boldsymbol{E}, \boldsymbol{F}$, Immunoreactivity of CbIn 1 (green) and VGluT1 or VGAT (red) in the hippocampus. The regions indicated by rectangles $(\boldsymbol{E})$ in the dentate gyrus molecular layer (DG-Mo) are enlarged in high-magnification images $(\boldsymbol{F})$. For comparison, co-immunostaining images of cerebellar molecular layer (Cb-ML) are shown in the lower panels. Scale bars: $E, 500 \mu \mathrm{m} ; \boldsymbol{F}, 5 \mu \mathrm{m}$.
}

ficity was ascertained by the lack of hybridizing signals using a sense riboprobe (Fig. $2 A$, inset).

Because Cbln1 is released from presynaptic neurons and exerts its function transsynaptically, we next examined Cbln1 protein localization. Interestingly, although Cbln 1 mRNA signals were mostly undetected in the hippocampus (Fig. 2), immunohistochemical analyses revealed that Cbln 1 was located at the molecular layer of the dentate gyrus and the stratum lacunosummoleculare of the hippocampus (Fig. $3 A, B$ ); these regions were further confirmed by immunostaining for VGluT2 (Fig. 3B; Herzog et al., 2006). Cbln1 immunoreactivity was also localized in the RSG, Cg, and LHb, but was undetected in the basolateral amygdala (Fig. 3A). RSG was characterized by the strong VGluT2 immunoreactivity at the superficial layer (Fig. 3C; Oda et al., 2014), which likely reflects inputs from the anteroventral nuclei of the thalamus (Fig. 2D,E). As reported previously (Miura et al., 2009), strong Cbln1 immunoreactivity was localized at the molecular layer of the cerebellum, where GluD2-immunopositive Purkinje cells were located (Fig. 3D).

To clarify relationships between Cbln 1 immunoreactivity and presynaptic terminals, we next immunostained Cbln1 together with VGluT1 or VGAT for excitatory or inhibitory inputs, respectively. Cbln 1 immunoreactive puncta were well colocalized with VGluT1, but not with VGAT immunoreactivities in the molecular layer of the dentate gyrus or in the molecular layer of the cerebellum (Fig. $3 E, F$ ), suggesting that Cbln 1 in the hippocampus is derived from excitatory input fibers (see the Discussion). Together, these results indicate that Cbln1 may function in extracerebellar brain regions, such as the hippocampus and RSG, which are reported to be involved in cue- and/or contextdependent fear conditioning (Kim and Fanselow, 1992; Maren and Holt, 2004; Hunsaker and Kesner, 2008; Keene and Bucci, 2008a, 2008b; Fanselow and Dong, 2010; Corcoran et al., 2011).

\section{Impaired non-motor learning in FB-Cbln1-null mice}

To examine the roles of Cbln 1 signaling in the forebrain, we generated $\operatorname{lox} P$-based conditional $C b \ln 1$-null mice $\left(C b \ln 1^{\text {flox/flox }}\right.$; Fig. $4 A$ ) and crossed them with a transgenic mice line that expressed Cre recombinase under the Camk2a promoter (Camk2aCre; Fig. 4B), which predominantly drives expression in the forebrain (Zeng et al., 2001). Immunohistochemical analyses revealed that Cbln 1 was significantly reduced in the molecular layer of the dentate gyrus, the stratum lacunosum-moleculare of the hippocampus, and RSG in Camk2a-Cre/+;Cbln1 $1^{\text {flox/flox }}$ mice compared with that in their littermate controls $C b \ln 1^{\text {flox/flox }}$ at 3-5 months; in contrast, no differences were observed in Cbln1 immunoreactivity in the cerebellum (Fig. $4 C, D$ ). Therefore, we hereafter refer to $C a m k 2 a-C r e /+; C b \ln 1^{\text {flox/flox }}$ mice as FBCbln1-null mice.

Because Camk2a-Cre-driven recombination of loxP occurs progressively in various brain regions (Zeng et al., 2001) during development, we also examined Cbln 1 expression in $\mathrm{FB}-\mathrm{Cb} \ln 1$ null mice at 1 month. Although Cbln 1 was significantly reduced in the FB-Cbln1-null hippocampus at 1 month and at 3-5 months, it was intact in the RSG of 1-month-old FB-Cbln1-null mice (Fig. $4 E$ ), suggesting that the involvement of RSG could be assessed by examining phenotypes of juvenile FB-Cbln1-null mice.

FB-Cbln1-null mice showed grossly normal appearance and body weight (control, $21.1 \pm 0.4 \mathrm{~g}, n=16$; FB-Cbln1-null, $20.9 \pm$ $0.5 \mathrm{~g}, n=14 ; p=0.747$ by Student's $t$ test) at $3-5$ months of age. In the open-field test, no differences were observed in total motor activity (control, $18 \pm 1 \mathrm{~m}, n=14$; FB-Cbln1-null, $21 \pm 2 \mathrm{~m}, n=12$; 
A

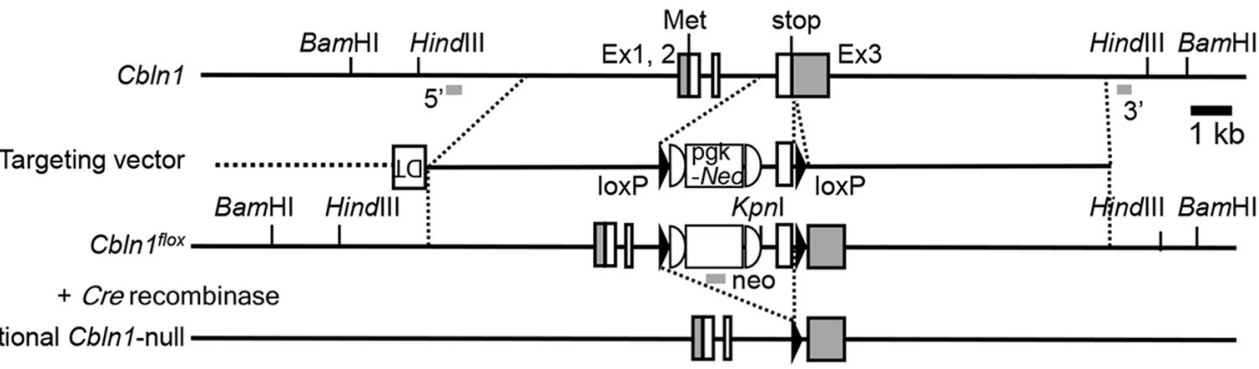

B

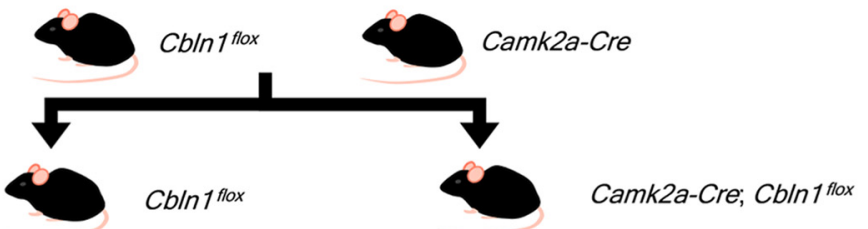

Control

C
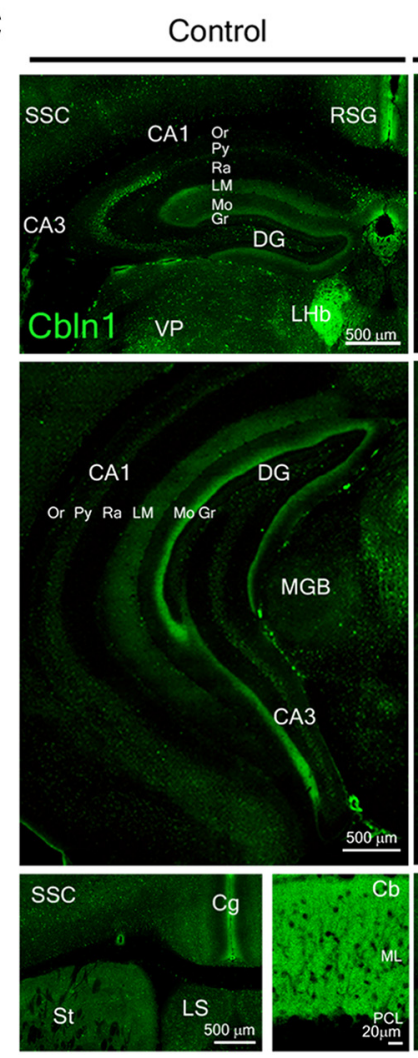

FB-cbln 1-null
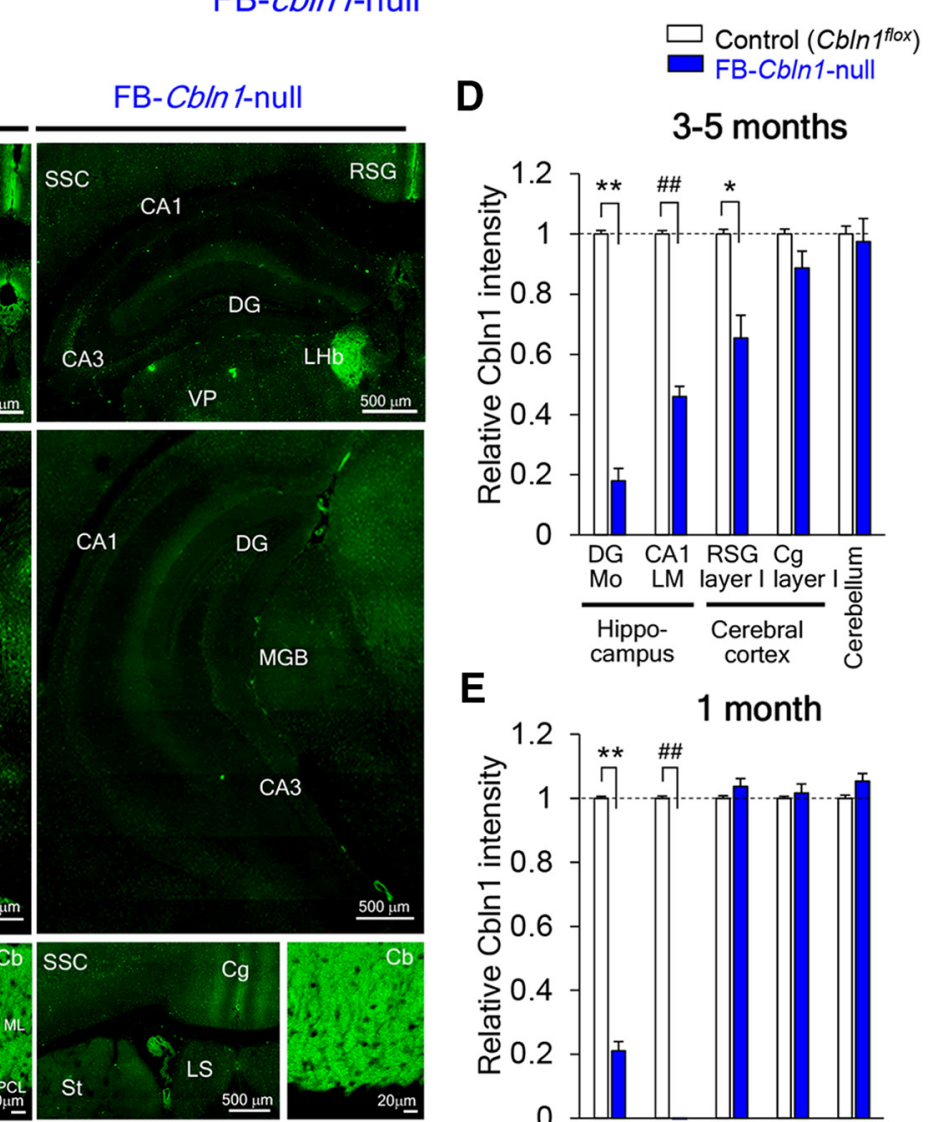

D
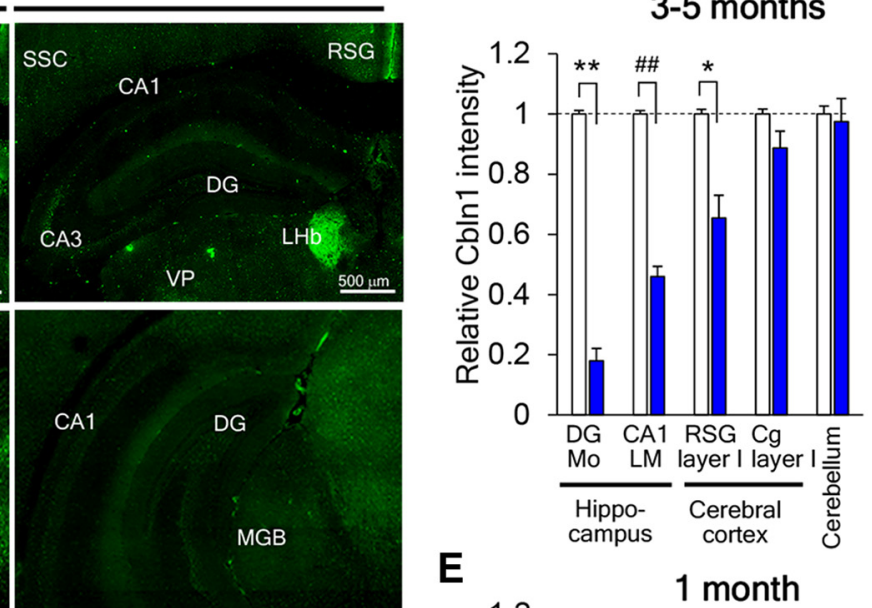

CA3

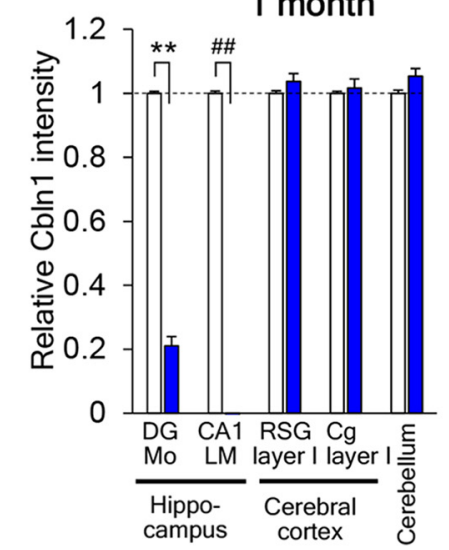

Figure 4. Generation and characterization of $\mathrm{FB}$ conditional $C b / n 1$-null mice. $A$, Schematic representation of the $C b / n 1$ genomic structure, targeting vector and targeted genes (Cbln $1^{\text {flox }}$ and

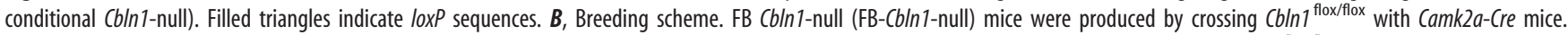
C, Immunohistochemical analyses of Cbln1 expression in FB-Cbln 1 -null mice at $3-5$ months of age. D, E, Cbln1 expression levels relative to those in control (Cbln $1^{\text {flox/flox }}$ ) mice. At 3-5 months, Cbln1 expression in the hippocampus (DG-Mo and LM) layer I of RSG was reduced in FB-Cbln1-null mice (D). ${ }^{* *} p=1.41 \times 10^{-6}$; \#\#p =0.0000338; ${ }^{*} p=0.0158$. At 1 month, Cbln1 expression was also reduced in the hippocampus, but not in RSG (E). ${ }^{* *} p=9.19 \times 10^{-6} ; \# \#=0.0000949 ; n=16$ images for each from $3-4$ animals, Mann-Whitney $U$ test. Cbln 1 expression in other brain regions, including Cg and cerebellum, was largely unaffected. For abbreviations, see the legend to Figure 3 . Scale bars, $20 \mu \mathrm{m}$ for the cerebellum and $500 \mu \mathrm{m}$ for the rest of the panels.

$p=0.18$ by Student's $t$ test) and the duration to stay at the center (control, $10 \pm 2 \%, n=14 ;$ FB-Cbln1-null, $9 \pm 2 \%, n=12 ; p=0.72$ by Student's $t$ test) between control and FB-Cbln1-null mice. Similarly, FB-Cbln1-null mice performed normal motor coordination in the rotarod test (Fig. 5A). FB-Cbln1-null mice also showed normal acoustic startle responses (Fig. 5B). These results indicate that basal anxiety levels and sensory-motor functions were largely unaffected in FB-Cbln1-null mice at 3-5 months.

Next, we investigated whether fear conditioning was affected in FB-Cbln1-null mice at 3-5 months of age. Interestingly, al- 

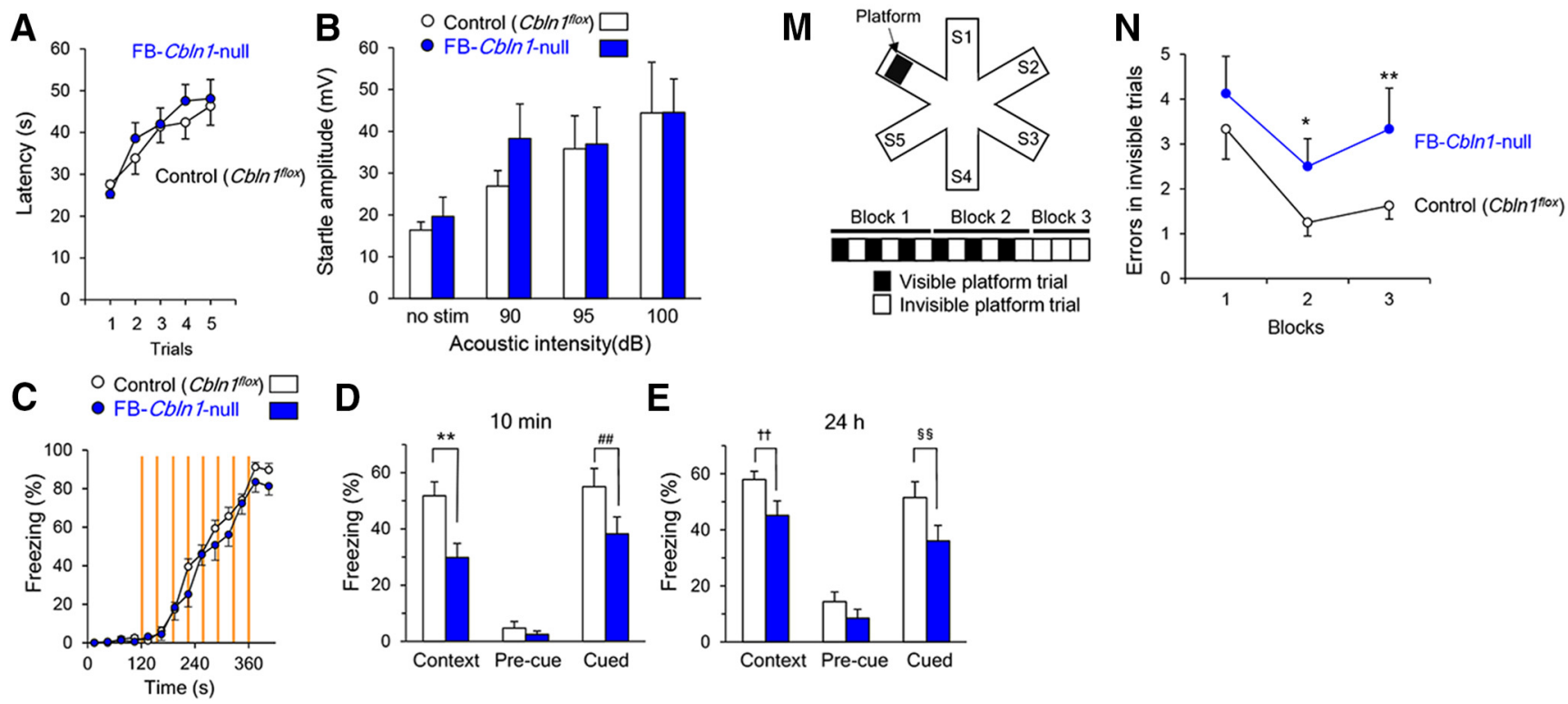

E

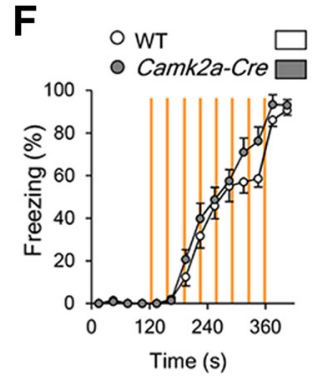

G

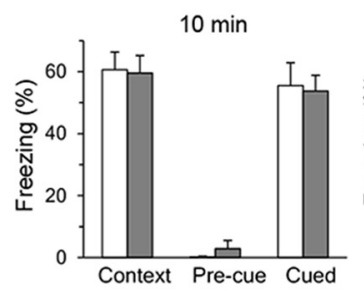

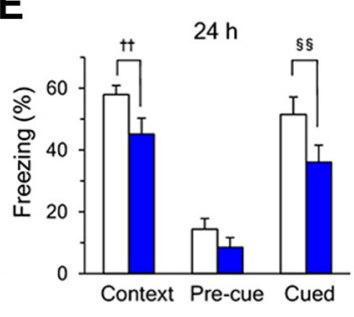

H

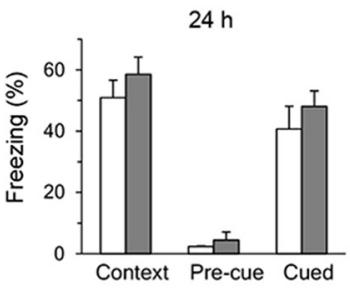

1 month
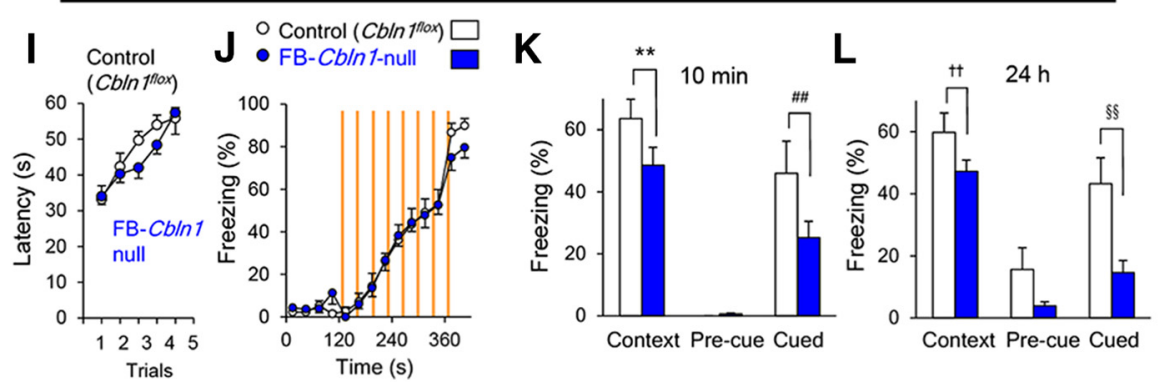

Figure 5. Impaired fear conditioning and spatial learning in FB-Cbln1-null mice. $\boldsymbol{A}-\boldsymbol{H}$, Phenotypes of adult (3- to 5-month-old) FB-Cbln1-null mice. Adult FB-Cb/n1-null mice showed normal rotarod test $(\boldsymbol{A})$ and acoustic startle reflex test $(\boldsymbol{B}) ; n=11$ for $\mathrm{FB}$-Cbln1-null and $n=12$ for control ( $\left(b / n 1^{\text {flox/flox }}\right)$ mice. Although no differences were observed between control and FB-Cbln 1 -null mice during acquisition $(\boldsymbol{C} ; p=0.19)$, contextual and cued memory were significantly impaired in adult $F B$-Cbln1-null mice at 10 min and $24 \mathrm{~h}$ after conditioning $\left(\boldsymbol{D}, \boldsymbol{E}_{\text {, }}^{* *} p=1.05 \times 10^{-6} ; \# \#=\right.$ $0.00766 ;+t p=0.00164 ; \S \S p=0.00196 ;$ control (Cbln $\left.1^{\text {flox/flox }}\right), n=14$, FB-Cbln1-null, $\left.n=13\right)$. In contrast, no differences were observed in acquisition $(\boldsymbol{F})$ and retention/retrieval of contextual and cued fear memory at $10 \mathrm{~min}(\mathbf{G})$ and $24 \mathrm{~h}(\boldsymbol{H})$ after conditioning between adult wild-type and Camk2a-Cre mice. $\boldsymbol{I}$ - $\boldsymbol{L}$, Phenotypes of juvenile (1-month-old) FB-Cbln 1-null mice. Juvenile FB-Cbln1-null mice showed normal rotarod test $(l) ; n=17$ for FB-Cbln1-null and $n=9$ for control ( $\left(b / n 1^{\text {floxfllox }}\right)$ mice. Like adult FB-Cbln1-null mice, although fear memory was acquired normally $(\boldsymbol{J})$, contextual and cued memory were significantly impaired in juvenile $F B$-Cbln1-null mice at $10 \mathrm{~min}$ and $24 \mathrm{~h}$ after conditioning $\left(\boldsymbol{K}, \boldsymbol{L},{ }^{* *} p=0.00696 ; \# \# p=0.0213 ; \dagger+, p=0.00323 ; \S \S, p=\right.$ 0.000131 ; control $\left(C b / n 1^{\text {flox } f l \text { lox }}\right), n=9$, FB-Cbln1-null, $\left.n=13\right) . M, N$, Impaired spatial learning in adult FB-Cbln1-null mice. A diagram showing the water radial maze test $(\boldsymbol{M})$. Mice were randomly placed in a start arm (S1-S5) and entries into arms without the platform in invisible trials were counted as errors. FB-Cbln1-null mice showed higher error number than controls $\left(\boldsymbol{N},{ }^{*} p=0.0455\right.$; ${ }^{* *} p=0.00735 ; n=8$ for each genotype).

though FB-Cbln1-null mice attained levels of freezing responses similar to the control $\left(C b \ln 1^{\text {flox/flox }}\right)$ mice during and immediately after the acquisition session (Fig. 5C), they showed significantly reduced context- and cue-dependent freezing at $10 \mathrm{~min}$ and $24 \mathrm{~h}$ after conditioning (Fig. 5D,E). No differences in acquisition and expression of context- and cue-conditioned fear memories were observed between wild-type and Camk2a-Cre mice (Fig. $5 F-H$ ), indicating that the impaired fear memory retention/ recall was caused by the loss of Cbln1 signaling in the forebrain regions.

Juvenile (1-month-old) FB-Cbln1-null mice showed essentially the same phenotypes: In the open-field test, FB-Cbln1-null and control mice moved similar distances (control, $12 \pm 2 \mathrm{~m}, n=$ 10 ; FB-Cbln1-null, $13 \pm 1 \mathrm{~m}, n=16$; $p=0.53$ by Student's $t$ test) and durations at the center (control, $5.0 \pm 1.1 \%, n=10$; FBCbln1-null, $4.9 \pm 0.8 \%, n=15 ; p=0.94$ by Student's $t$ test). The 
A

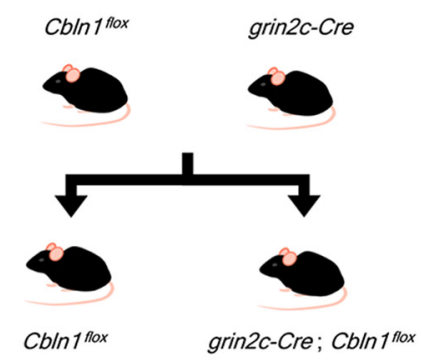

Control
B

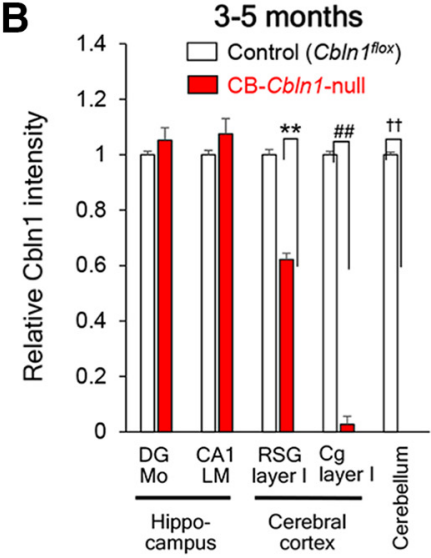

C

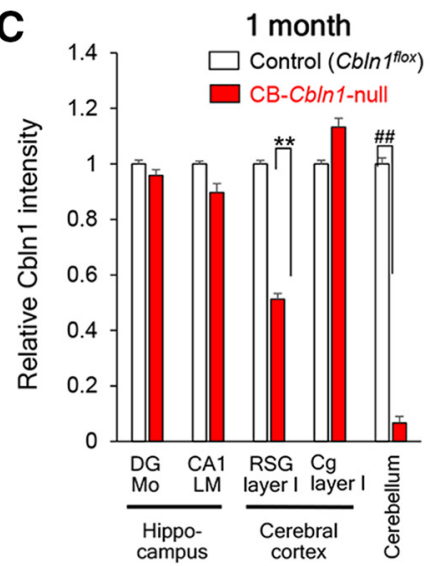

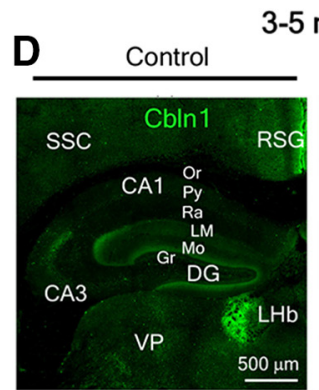
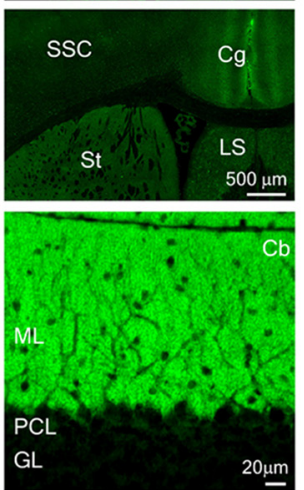

3-5 months
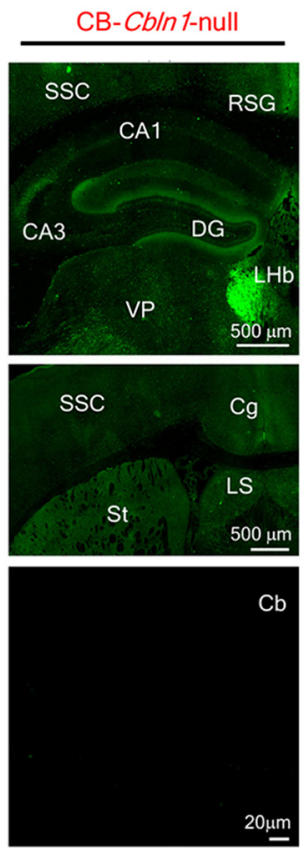

E
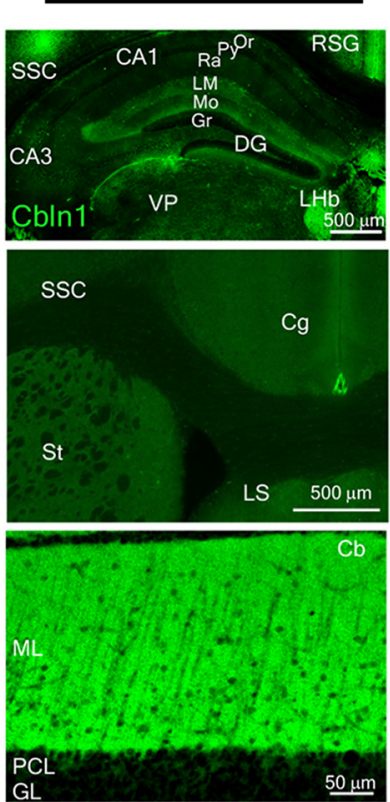

1 month
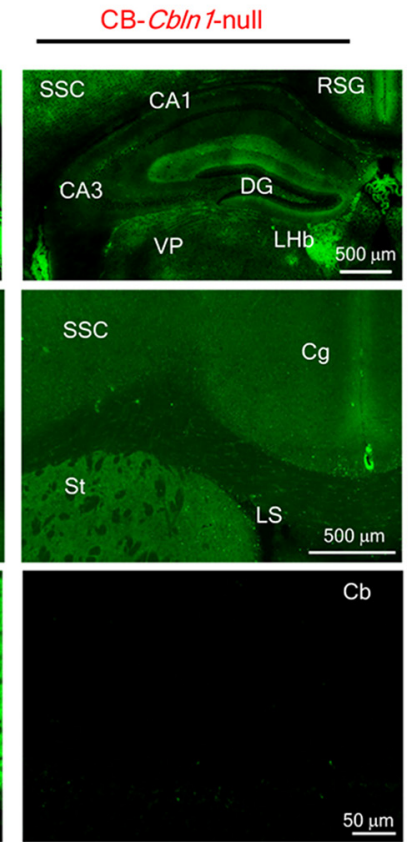

Figure 6. Generation and characterization of $C B$ conditional $C b / n 1$-null mice. $A$, Breeding scheme. CB-Cbln1-null mice were produced by crossing Cbln $1^{\text {flox/flox }}$ with Grin2 $C^{\text {Cre/ }+}$ mice. $B-E$, Immunohistochemical analyses of $\mathrm{Cb} \mid \mathrm{n} 1$ at adult (3- to 5-month-old; $\boldsymbol{B}, \boldsymbol{D})$ and juvenile (1-month-old; $\boldsymbol{C}, \boldsymbol{E}$ ) CB-Cbln1-null mice. (bln1 immunoreactivity was significantly reduced in the RSG in addition to the cerebellum in both juvenile and adult CB-Cb/n1-null mice. It was also reduced in the C $\mathrm{g}$ in adult CB-Cb/n1-null mice. For abbreviations, see the legend to Figure 3. Scale bars, $20 \mu \mathrm{m}$ for the cerebellum and $500 \mu \mathrm{m}$ for the rest of the panels. Cbln1 expression levels relative to those in the control mice are shown $\left(\boldsymbol{B} ;{ }^{* *} p=5.31 \times 10^{-5} ; \# \# p=3.23 \times 10^{-5} ;+t p=7.02 \times\right.$ $10^{-11} ; n=16$ where $n$ is the number of images derived from $3-4$ animals for each genotype). $C^{* *} p=3.23 \times 10^{-5} ; \# p=3.22 \times 10^{-5} ; n=12$ where $n$ is the number of images derived from 3 animals for each genotype, Mann-Whitney $U$ test).

rotarod test performance was also normal (Fig. 5I). In contrast, although freezing responses were normally acquired (Fig. $5 \mathrm{~J}$ ), juvenile FB-Cbln1-null mice showed reduced freezing responses in context and cued tests at $10 \mathrm{~min}$ and $24 \mathrm{~h}$ after conditioning (Fig. $5 K, L$ ). These results are consistent with the reduced Cbln1 expression in the hippocampus of FB-Cbln1-null mice at 1 month of age (Fig. $4 E$ ) and suggest that Cbln 1 in the RSG may not play major roles in the fear conditioning.

To further examine the function of Cbln 1 in the forebrain, we performed the radial arm water maze test on FB-Cbln1-null mice at 3-5 months of age (Fig. $5 M$ ). A platform was placed at one of the six arms as a goal and entries into the arm without the platform were counted as errors. No differences were observed between control and FB-Cbln1-null mice when the platform was visible (control, $2.2 \pm 0.7, n=8$; FB- $C b \ln 1$-null, $2.0 \pm 0.5, n=8$; $p=0.81$ by Student's $t$ test), indicating that FB-Cbln1-null mice have no deficit in visual or motor performances. In contrast, FB-Cbln1-null mice showed larger numbers of errors than did the controls during the invisible trials in blocks 2 and 3 (Fig. $5 N$ ). Together, these data indicate that Cbln 1 in the forebrain regions is involved in non-motor learning in adult mice.

\section{Cerebellar Cbln1 likely contributes to fear learning}

To clarify whether cerebellar Cbln1 contributes to the non-motor functions, we next crossed $C b \ln 1^{\text {flox/flox }}$ mice with knock-in mice that expressed Cre under the control of the gene encoding GluN2C (Grin2C), which is predominantly expressed in cerebellar granule cells (Fig. 6A; Miyazaki et al., 2012). Immunohistochemical analyses revealed that Cbln 1 was essentially absent in the cerebellum of Grin $2 C^{\mathrm{Cre} /+} ; C b \ln 1^{\text {flox/flox }}$ mice (Fig. $6 B-E$ ), a result consistent with the ISH data showing predominant expression of Cbln1 mRNA in cerebellar granule cells (Fig. $2 A, J, L$; 
Miura et al., 2006). At 3-5 months of age, Cbln1 immunoreactivity was largely unaffected in the forebrain region of these mice, except for the RSG and Cg, compared with their littermate control $C b \ln 1^{\text {flox/flox }}$ mice (Fig. $6 B, D$ ). At 1 month, the reduction of Cbln1 immunoreactivity was only observed in the RSG in the forebrain regions (Fig. $6 C, E$ ). Therefore, we refer to Grin $2 C^{\mathrm{Cre} /+}$; $C b \ln 1^{\text {flox/flox }}$ mice as CB-Cbln1-null mice.

Like general Cbln1-null mice, adult (3-5 months old) CBCbln1-null mice showed smaller body weight (control, $21.9 \pm$ $0.4 \mathrm{~g}, n=18$; CB-Cbln1-null, $19.9 \pm 0.4 \mathrm{~g}, n=21 ; p=0.00092$ by Student's $t$ test) and shorter latency to fall in the rotarod test (Fig. $7 A$ ). Similarly, in the open-field test, CB-Cbln1-null mice stayed significantly longer at the center (control, $6 \pm 2 \%, n=9$; CBCbln1-null, $15 \pm 3 \%, n=11 ; p=0.0363$ by Student's $t$ test) and tended to show reduced motor activities (control, $14 \pm 2 \mathrm{~m}, n=$ 11; CB-Cbln1-null, $9 \pm 2 \mathrm{~m}, n=11 ; p=0.08$ by Student's $t$ test). Their auditory startle responses were intact (Fig. $7 B$ ). Interestingly, adult CB-Cbln1-null mice showed impaired context- and cue-dependent fear condition during acquisition (Fig. 7C) and retention/expression at $10 \mathrm{~min}$ and $24 \mathrm{~h}$ after the acquisition (Fig. $7 D, E)$ compared with littermate controls $\left(C b \ln 1^{\text {flox/flox }}\right)$. Because one allele of the Grin2C gene was disrupted in $\mathrm{CB}-\mathrm{Cb} \ln 1$-null mice, we next assessed fear conditioning in Grin $2 C^{\mathrm{Cre} /+}$ mice. No differences were observed in fear conditioning between control (wild-type) and Grin $2 \mathrm{C}^{\mathrm{Cre} /+}$ mice (Fig. $7 \mathrm{~F}-\mathrm{H}$ ), indicating that the loss of one Grin2C allele did not affect fear conditioning.

Finally, to further assess the effect of Cbln 1 expression in the $\mathrm{Cg}$, we used CB-Cbln1-null mice at 1 month of age, when Cbln 1 in the $\mathrm{Cg}$ was not reduced (Fig. $6 C$ ). Like general Cbln1-null mice at 1 month (Fig. $1 L$ ), CB-Cbln1-null already showed poor performance in the rotarod test (Fig. 7I), but their motor activities (control, $13.5 \pm 0.7 \mathrm{~m}, n=12$; CB-Cbln1-null, $11.0 \pm 1.0 \mathrm{~m}, n=$ $13 ; p=0.18$ by Student's $t$ test) and durations to stay at the center (control, $5 \pm 1 \%, n=12$; CB-Cbln1-null, $7 \pm 2 \%, n=13 ; p=$ 0.37 by Student's $t$ test) were similar to those of wild-type mice in the open-field test. Like general Cbln1-null mice at 1 month (Fig. $1 M-O), \mathrm{CB}-\mathrm{Cb} \ln 1$-null mice showed slightly but significantly lower levels of freezing responses than did the control $\left(C b \ln 1^{\text {flox/flox }}\right)$ mice during and immediately after the acquisition session (Fig. 7J). In addition, they showed significantly reduced context- and cue-dependent freezing responses at $10 \mathrm{~min}$ and reduced cue-dependent freezing at $24 \mathrm{~h}$ after conditioning (Fig. $7 K, L)$. To determine whether the retention/recall defects were caused by impaired acquisition in CB-Cbln1-null mice, we performed post hoc analyses of a subpopulation of CB-Cbln1-null mice that displayed freezing responses to a level similar to that of control mice immediately after the acquisition period (Fig. 7M). These CB-Cbln1-null mice showed levels of freezing responses similar to those shown by control mice at $10 \mathrm{~min}$ (Fig. $7 \mathrm{~N}$ ) and $24 \mathrm{~h}$ (Fig. 7O) after the conditioning. Together, these results indicate that cerebellar Cbln1 contributes to fear learning, especially during the acquisition period.

\section{Discussion}

In the present study, we have shown that fear conditioning is impaired in mice lacking Cbln1, a protein that plays an essential role at PF-Purkinje cell synapses in the cerebellum. Immunohistochemical analyses revealed that Cbln 1 was present, not only in the cerebellar granule cells, but also in the forebrain regions including the hippocampus, RSG, and Cg. Using FB- and CB$C b \ln 1$-null mice, we found that Cbln 1 mediated specific aspects of fear conditioning both in the forebrain and the cerebellum (Table 2).

\section{Cbln1 signaling in the forebrain region}

Cbln 1 was originally identified as a precursor of the Purkinje celland dorsal cochlear nucleus-specific peptide cerebellin (Slemmon et al., 1984; Mugnaini and Morgan, 1987). Although Cbln1 mRNA signals were expressed predominantly in the cerebellar granule cells, which are the most numerous and densely packed neurons in the brain, our chromogenic ISH analyses detected Cbln 1 mRNAs in various extracerebellar brain regions (Fig. 2A). These results are largely consistent with those of our previous ISH analyses using a radiolabeled oligonucleotide probe (Miura et al., 2006); however, we have identified finer localizations of Cbln1 mRNAs at the level of layers and nuclei in various brain regions (Table 1). Cbln1 immunoreactivity was detected in the brain regions expressing Cbln 1 mRNAs, with an important exception for the hippocampus, where Cbln1 immunoreactivity was present at the molecular layer of the dentate gyrus and the stratum lacunosum-moleculare without overt mRNA expression (Figs. $2 A, 3 A, B)$. In contrast, Cbln1 immunoreactivity was reported previously to be undetectable in the hippocampus (Wei et al., 2007). However, in this earlier report, Cbln1 immunoreactivity was localized to the cytoplasm of neurons immunopositive for cathepsin D, a lysosomal marker. In addition, Cbln 1 immunoreactivity completely recapitulated the pattern of expression of $\beta$-galactosidase expressed under the $C b \ln 1$ promotor (Wei et al., 2007), indicating that the reported Cbln 1 immunoreactivity likely reflects Cbln 1 in the lysosomal compartment in neurons producing and/or degrading Cbln1.

In contrast, punctate Cbln 1 immunoreactivity was detected at synaptic clefts between PFs and Purkinje cells in the cerebellum after antigen-unmasking procedures (Miura et al., 2009), which are often required to detect protein epitopes located at postsynaptic densities and synaptic clefts (Watanabe et al., 1998; Lorincz and Nusser, 2008). Using freshly frozen sections without transcardiac perfusion, by which certain antigens located at synapses are likely unmasked, we detected Cbln1-immunopositive puncta colocalized with VGluT1 immunoreactivities at the molecular layer of the dentate gyrus, as well as at the molecular layer of the cerebellum (Fig. 3F). Whereas Purkinje cells completely lack Cbln1 mRNAs (Fig. 2J,L), Cbln1-immunopositive puncta were highly accumulated along their dendrites in the molecular layer (Fig. 3D) because Cbln 1 released from PFs (axons of granule cells; Hirai et al., 2005; Miura et al., 2009) bound to GluD2 expressed on Purkinje cell dendrites (Matsuda et al., 2010). Considering that the entorhinal cortex, which sends performant pathway fibers to these hippocampal regions, expressed Cbln 1 mRNAs (Fig. $2 \mathrm{H}$ ), we propose that Cbln 1 is released from performant path axons and associates with GluD1, a family member of GluD2 that binds to Cbln1 in vitro (Matsuda et al., 2010) and is expressed in the hippocampus (Hepp et al., 2015; Konno et al., 2014).

Impaired fear conditioning in adult FB-Cbln1-null mice is the first demonstration that Cbln 1 plays an essential role in cognitive functions in extracerebellar brain regions in vivo. The dorsal hippocampus and RSG are thought to mediate retrieval/retention of context-dependent fear memory (Kim and Fanselow, 1992; Keene and Bucci, 2008a, 2008b; Corcoran et al., 2011). The ventral hippocampus is thought to mainly mediate retention/retrieval of cue-dependent fear memory; however, it also affects contextual memory (Maren and Holt, 2004; Hunsaker and Kesner, 2008; Fanselow and Dong, 2010). Because fear conditioning was similarly impaired in 1-month-old FB-Cbln1-null mice (Fig. $5 J-L)$, in which Cbln1 immunoreactivity is reduced in the hippocampus, but not in RSG or Cg (Fig. $4 E$, Table 2), Cbln 1 in the hippocampus (Fig. 4C-E) likely contributes to impaired cue- and 


\section{3-5 months}

A

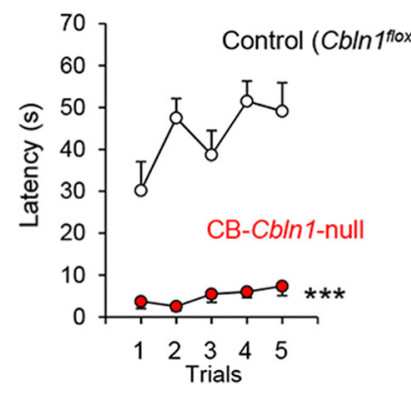

B $\square$ WT

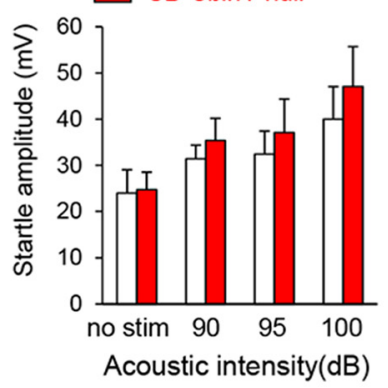

C $\circ$ Control $\left(C b / n^{\text {trox }}\right) \square$ - CB-Cbln 1-null

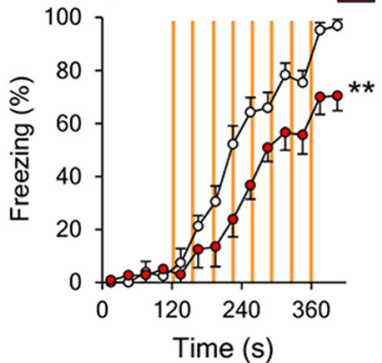

$\mathbf{F}$

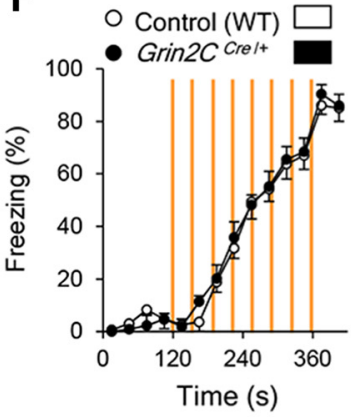

D

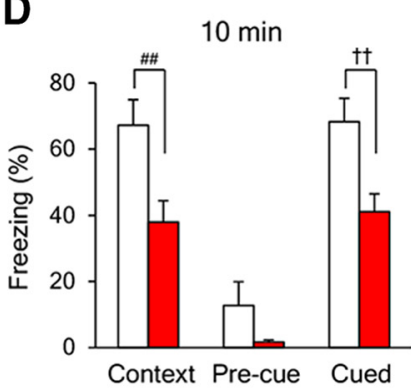

G

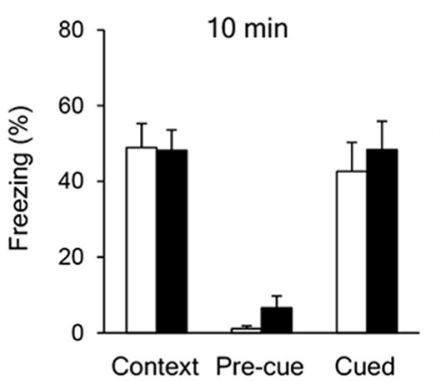

E

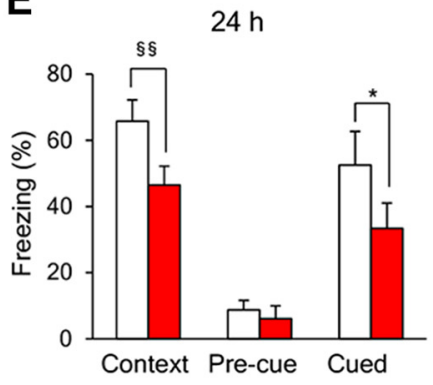

H

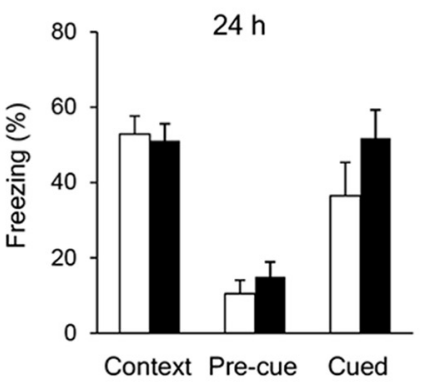

\section{1 month}

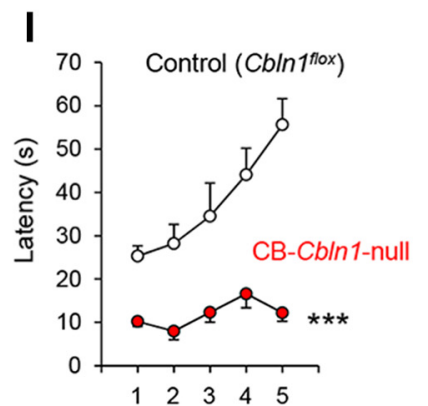

J
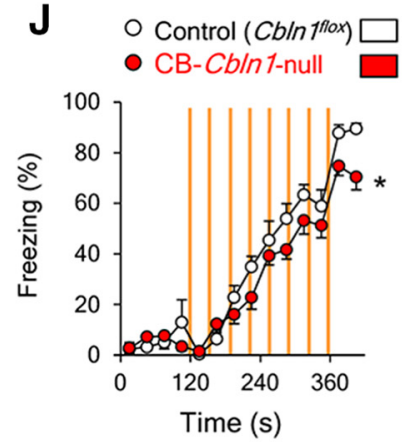

M
K

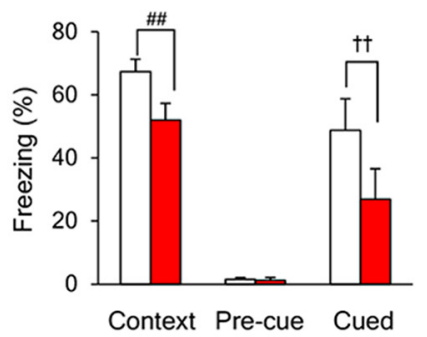

N
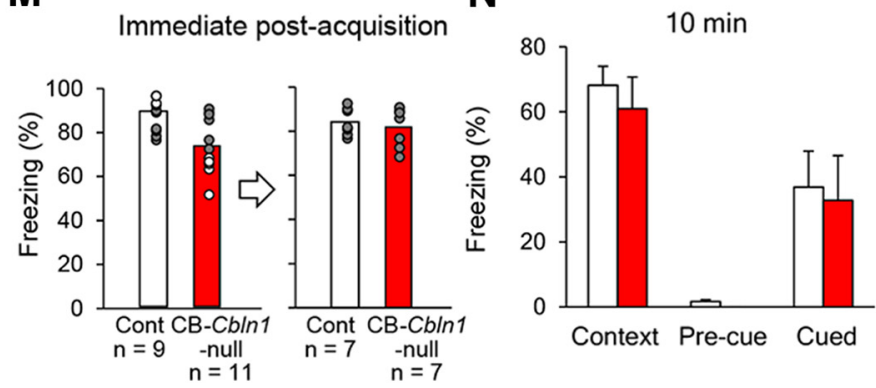

L

$24 \mathrm{~h}$

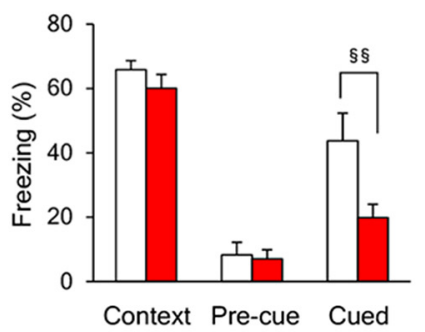

0

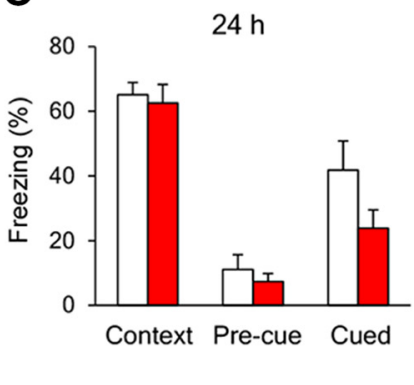

Figure 7. Impaired fear conditioning in CB-Cbln1-null mice. $\boldsymbol{A}-\boldsymbol{H}$, Phenotypes of adult (3- to 5-month-old) $\mathrm{CB}$-Cbln1-null mice. Adult CB-Cbln1-null mice showed significantly shorter latency to fall in the rotarod test $\left(\boldsymbol{A} ;{ }^{* * *} p=1.68 \times 10^{-8}\right)$, but normal acoustic startle response $(\boldsymbol{B})$. Control $\left(\mathrm{Cbln} 7^{\text {flox/flox }}\right), n=10, \mathrm{CB}$ - Cbln 1 -null, $n=11$. Acquisition $(\boldsymbol{C})$ and retention/retrieval at 10 min

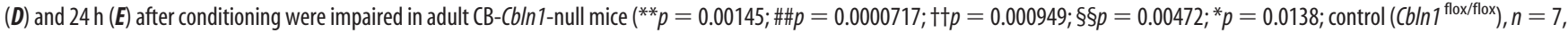
(B-Cbln1-null, $n=10)$. No differences were observed in acquisition $(\boldsymbol{F})$ and retention/retrieval of fear memory at $10 \mathrm{~min}(\boldsymbol{G})$ and $24 \mathrm{~h}(\boldsymbol{H})$ after conditioning between control (wild-type) and

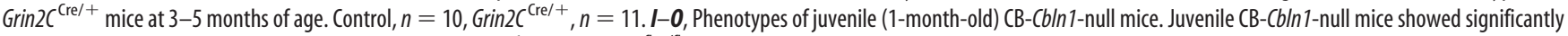
shorter latency to fall in the rotarod test $(I ; * * *)=1.14 \times 10^{-6}$; $\operatorname{control}\left(C b \ln 7^{\text {flox/flox }}\right), n=10,(B-C b \ln 1$-null, $n=10)$. Acquisition $(J)$ and retention/retrieval of contextual and cued fear memory at $10 \mathrm{~min}(\boldsymbol{K})$ and cued memory at $24 \mathrm{~h}(\boldsymbol{L})$ after conditioning were impaired in $\mathrm{CB}$-Cbln1-null mice at 1 month ${ }^{*} p=0.0234 ; \# \# p=0.000865$; ††p $=0.00934 ; \S \S p=0.00489$; control (Cbln $\left.1^{\text {flox/flox }}\right), n=9$, (B-Cbln1-null, $\left.n=11\right)$. Subpopulations of control mice that showed less freezing and CB-Cbln1-null mice that showed more freezing were selected arbitrarily in post hoc analyses so that both groups showed a similar levels of acquisition of fear memory $(\boldsymbol{M})$. The subpopulations of juvenile CB-Cb/n1-null mice showed similar levels of freezing responses to those shown

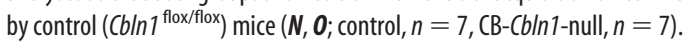


Table 2. Summary of phenotypes of general and conditional Cbln1-null mice

\begin{tabular}{|c|c|c|c|c|c|c|c|c|c|c|c|}
\hline \multirow[b]{2}{*}{ Genotype } & \multirow[b]{2}{*}{ Age $(\mathrm{mo})$} & \multicolumn{4}{|c|}{ Major affected brain regions } & \multicolumn{3}{|c|}{ Fear conditioning } & \multicolumn{2}{|c|}{ Open-field } & \multirow[b]{2}{*}{ Rotarod } \\
\hline & & CB & RSG & $\mathrm{Cg}$ & Hippocampus & Acquisition & Context & Cued & Activity & Center & \\
\hline \multirow[t]{2}{*}{ Cbln1-null } & 1 & $\downarrow$ & $\downarrow$ & $\downarrow$ & $\downarrow$ & $\downarrow$ & $\downarrow$ & $\downarrow$ & $\downarrow$ & $\rightarrow$ & $\downarrow$ \\
\hline & $3-5$ & $\downarrow$ & $\downarrow$ & $\downarrow$ & $\downarrow$ & $\downarrow$ & $\downarrow$ & $\downarrow$ & $\downarrow$ & $\uparrow$ & $\downarrow$ \\
\hline \multirow[t]{2}{*}{ FB-Cbln1-null } & 1 & $\rightarrow$ & $\rightarrow$ & $\rightarrow$ & $\downarrow$ & $\rightarrow$ & $\downarrow$ & $\downarrow$ & $\rightarrow$ & $\rightarrow$ & $\rightarrow$ \\
\hline & $3-5$ & $\rightarrow$ & $\downarrow$ & $\rightarrow$ & $\downarrow$ & $\rightarrow$ & $\downarrow$ & $\downarrow$ & $\rightarrow$ & $\rightarrow$ & $\rightarrow$ \\
\hline \multirow[t]{2}{*}{ CB-Cbln1-null } & 1 & $\downarrow$ & $\downarrow$ & $\rightarrow$ & $\rightarrow$ & $\downarrow$ & $\downarrow *$ & $\downarrow$ & $\rightarrow$ & $\rightarrow$ & $\downarrow$ \\
\hline & $3-5$ & $\downarrow$ & $\downarrow$ & $\downarrow$ & $\rightarrow$ & $\downarrow$ & $\downarrow$ & $\downarrow$ & $\rightarrow \downarrow$ & $\uparrow$ & $\downarrow$ \\
\hline
\end{tabular}

$\downarrow$, reduced; $\rightarrow$, no change; $\rightarrow \downarrow$, tendency to reduce.

*Reduced at $10 \mathrm{~min}$ but not at $24 \mathrm{~h}$ after conditioning.

context-dependent fear memory in juvenile and adult FB-Cbln1null mice. However, whereas acquisition of fear conditioning was unaffected in FB-Cbln1-null mice (Fig. 5C, $J$ ), it was impaired when the ventral hippocampus was inactivated globally by electrolysis or drug infusions (Maren and Holt, 2004; Hunsaker and Kesner, 2008). Therefore, loss of Cbln1 may affect specific synapses in the hippocampus that are necessary for retention/retrieval of fear memory without affecting the acquisition phase. The loss of Cbln 1 may also have affected brain regions other than the hippocampus in FB-Cbln1-null mice. For example, the spine density of medium spiny neurons was reported to increase in the striatum of Cbln1-null mice (Kusnoor et al., 2010); Cbln1 in the striatum may be derived from thalamic and/or cortical inputs because Cbln $1 \mathrm{mRNA}$ is not expressed there (Fig. 2A, D, Table 1). The use of a conditional $C b \ln 1$ knock-out more specific to the subtypes of neurons and brain regions will be necessary to further clarify where and how Cbln1 mediates retention/retrieval of fear memory in the forebrain.

Like $C b \ln 1$, many genes predominantly expressed in the cerebellum are detected in small populations of neurons in other brain regions at lower levels. For example, although GluD2 was thought to be expressed exclusively in cerebellar Purkinje cells (Araki et al., 1993; Lomeli et al., 1993), low levels of GluD2 were reported recently in the hippocampus, $\mathrm{Cg}$, and cerebral cortex (Hepp et al., 2015; Konno et al., 2014). Mutations in the GRID2 gene are associated with ASD (Gazzellone et al., 2014; Pinto et al., 2014) and cognitive impairment (Hills et al., 2013; Utine et al., 2013; Maier et al., 2014) in humans. Our findings on fear conditioning in FB-Cbln1-null mice indicate that the roles of GRID2, and possibly other cerebellar-predominant genes, in extracerebellar regions need to be assessed carefully when assigning cognitive functions to the cerebellum.

\section{Contribution of the cerebellum to fear conditioning}

Acquisition of fear conditioning was impaired significantly in juvenile and adult CB-Cbln1-null (Fig. 7C, J) and Cbln1-null mice (Fig. 1F,M). Although Cbln1 immunoreactivity was commonly reduced in RSG in addition to the cerebellum in both juvenile and adult CB-Cbln1-null mice (Fig. $6 B, C$ ), acquisition of fear conditioning was intact in adult FB-Cbln1-null mice (Fig. $5 C$ ), in which Cbln1 was also reduced in RSG (Fig. 4D, Table 2). Despite motor discoordination and ataxia, the sensorimotor systems necessary for fear conditioning were largely intact in Cbln1null mice (Fig. 1D; Emi et al., 2013). In addition, freezing responses to the predator odor were similarly observed in wildtype and $C b \ln 1$-null mice (Fig. $1 E$ ). Therefore, Cbln 1 signaling in the cerebellum is likely responsible for the acquisition of cued and contextual fear memory.

Acquisition and retention/retrieval of fear memory were reported previously to be intact in two cerebellum-specific mutant mice lines, $L 7-$ gabra2 $2^{-1-}$ and $L 7-S l c 12 a 5^{-1-}$, in which inhibitory inputs to Purkinje cells were compromised (Galliano et al., 2013). These mice also showed normal social interaction and spatial orientation in the Morris water maze. Although inhibitory inputs that modulate the duration of Purkinje cell firing were absent, other major synaptic inputs such as climbing fibers, PFs, and mossy fibers were intact in these mice. In addition, synaptic plasticity at PF-Purkinje cells was unaffected in L7-gabra2 ${ }^{-1-}$ mice (Wulff et al., 2009). In contrast, the number of PF-Purkinje cell synapses was severely reduced and long-term depression was absent in Cbln1-null mice (Hirai et al., 2005). Therefore, the discrepancy may be explained by the less severe functional impairment in the $L 7-$ gabra $2^{-1-}$ and $L 7-S l c 12 a 5^{-1-}$ cerebellum. Indeed, two of five ASD mouse models, L7-Cre; tsc $1^{+/ \text {flox }}$ and Shank $3^{+/ \Delta C}$, in which disrupted genes were specifically expressed in the cerebellum, showed ASD-related behaviors such as impaired social behavior, repetitive behaviors, and ultrasonic vocalization (Kloth et al., 2015). Interestingly, delayed eye-blink conditioning, a form of associative sensory learning, was also perturbed in these mice. Cerebellar circuits play essential roles in determining the adaptive timing of conditioned responses by associating an air puff (US) with tone (Koekkoek et al., 2003) and other sensory modalities (Ohmae and Medina, 2015) during eyeblink conditioning. It is thus possible that the cerebellum, by communicating with the forebrain, may help to integrate US with sensory modalities in a time window during the acquisition phase of cued and contextual fear conditioning. To understand how the cerebellar circuits contribute to cognitive functions associated with ASD and psychiatric disorders, further studies on eye-blink and fear conditioning in mice, in which genes are manipulated in a synapse-specific manner, are warranted.

\section{References}

Alamed J, Wilcock DM, Diamond DM, Gordon MN, Morgan D (2006) Two-day radial-arm water maze learning and memory task; robust resolution of amyloid-related memory deficits in transgenic mice. Nat Protoc 1:1671-1679. CrossRef Medline

Araki K, Meguro H, Kushiya E, Takayama C, Inoue Y, Mishina M (1993) Selective expression of the glutamate receptor channel delta 2 subunit in cerebellar Purkinje cells. Biochem Biophys Res Commun 197:1267-1276. CrossRef Medline

Bostan AC, Dum RP, Strick PL (2013) Cerebellar networks with the cerebral cortex and basal ganglia. Trends Cogn Sci 17:241-254. CrossRef Medline

Buckner RL, Krienen FM, Castellanos A, Diaz JC, Yeo BT (2011) The organization of the human cerebellum estimated by intrinsic functional connectivity. J Neurophysiol 106:2322-2345. CrossRef Medline

Burguière E, Arleo A, Hojjati Mr, Elgersma Y, De Zeeuw CI, Berthoz A, Rondi-Reig L (2005) Spatial navigation impairment in mice lacking cerebellar LTD: a motor adaptation deficit? Nat Neurosci 8:1292-1294. CrossRef Medline

Corcoran KA, Donnan MD, Tronson NC, Guzmán YF, Gao C, Jovasevic V, Guedea AL, Radulovic J (2011) NMDA receptors in retrosplenial cortex 
are necessary for retrieval of recent and remote context fear memory. J Neurosci 31:11655-11659. CrossRef Medline

Emi K, Kakegawa W, Miura E, Ito-Ishida A, Kohda K, Yuzaki M (2013) Reevaluation of the role of parallel fiber synapses in delay eyeblink conditioning in mice using Cbln1 as a tool. Front Neural Circuits 7:180. CrossRef Medline

Fanselow MS, Dong HW (2010) Are the dorsal and ventral hippocampus functionally distinct structures? Neuron 65:7-19. CrossRef Medline

Fukudome Y, Ohno-Shosaku T, Matsui M, Omori Y, Fukaya M, Tsubokawa H, Taketo MM, Watanabe M, Manabe T, Kano M (2004) Two distinct classes of muscarinic action on hippocampal inhibitory synapses: M2mediated direct suppression and M1/M3-mediated indirect suppression through endocannabinoid signalling. Eur J Neurosci 19:2682-2692. CrossRef Medline

Galliano E, Potters JW, Elgersma Y, Wisden W, Kushner SA, De Zeeuw CI, Hoebeek FE (2013) Synaptic transmission and plasticity at inputs to murine cerebellar Purkinje cells are largely dispensable for standard nonmotor tasks. J Neurosci 33:12599-12618. CrossRef Medline

Gazzellone MJ, Zhou X, Lionel AC, Uddin M, Thiruvahindrapuram B, Liang S, Sun C, Wang J, Zou M, Tammimies K, Walker S, Selvanayagam T, Wei J, Wang Z, Wu L, Scherer SW (2014) Copy number variation in Han Chinese individuals with autism spectrum disorder. J Neurodev Disord 6:34. CrossRef Medline

Hepp R, Hay YA, Aguado C, Lujan R, Dauphinot L, Potier MC, Nomura S, Poirel O, El Mestikawy S, Lambolez B, Tricoire L (2015) Glutamate receptors of the delta family are widely expressed in the adult brain. Brain Struct Funct 220:2797-2815. CrossRef Medline

Herzog E, Takamori S, Jahn R, Brose N, Wojcik SM (2006) Synaptic and vesicular co-localization of the glutamate transporters VGLUT1 and VGLUT2 in the mouse hippocampus. J Neurochem 99:1011-1018. CrossRef Medline

Hills LB, Masri A, Konno K, Kakegawa W, Lam AT, Lim-Melia E, Chandy N, Hill RS, Partlow JN, Al-Saffar M, Nasir R, Stoler JM, Barkovich AJ, Watanabe M, Yuzaki M, Mochida GH (2013) Deletions in GRID2 lead to a recessive syndrome of cerebellar ataxia and tonic upgaze in humans. Neurology 81:1378-1386. CrossRef Medline

Hirai H, Pang Z, Bao D, Miyazaki T, Li L, Miura E, Parris J, Rong Y, Watanabe M, Yuzaki M, Morgan JI (2005) Cbln1 is essential for synaptic integrity and plasticity in the cerebellum. Nat Neurosci 8:1534-1541. CrossRef Medline

Hunsaker MR, Kesner RP (2008) Dissociations across the dorsal-ventral axis of CA3 and CA1 for encoding and retrieval of contextual and auditory-cued fear. Neurobiol Learn Mem 89:61-69. CrossRef Medline

Ito M (2001) Cerebellar long-term depression: characterization, signal transduction, and functional roles. Physiol Rev 81:1143-1195. Medline

Jones RM, Cadby G, Melton PE, Abraham LJ, Whitehouse AJ, Moses EK (2013) Genome-wide association study of autistic-like traits in a general population study of young adults. Front Hum Neurosci 7:658. CrossRef Medline

Kakegawa W, Mitakidis N, Miura E, Abe M, Matsuda K, Takeo YH, Kohda K, Motohashi J, Takahashi A, Nagao S, Muramatsu S, Watanabe M, Sakimura K, Aricescu AR, Yuzaki M (2015) Anterograde Clql1 signaling is required in order to determine and maintain a single-winner climbing fiber in the mouse cerebellum. Neuron 85:316-329. CrossRef Medline

Keene CS, Bucci DJ (2008a) Contributions of the retrosplenial and posterior parietal cortices to cue-specific and contextual fear conditioning. Behav Neurosci 122:89-97. CrossRef Medline

Keene CS, Bucci DJ (2008b) Neurotoxic lesions of retrosplenial cortex disrupt signaled and unsignaled contextual fear conditioning. Behav Neurosci 122:1070-1077. CrossRef Medline

Kim JJ, Fanselow MS (1992) Modality-specific retrograde amnesia of fear. Science 256:675-677. CrossRef Medline

Kloth AD, Badura A, Li A, Cherskov A, Connolly SG, Giovannucci A, Bangash MA, Grasselli G, Peñagarikano O, Piochon C, Tsai PT, Geschwind DH, Hansel C, Sahin M, Takumi T, Worley PF, Wang SS (2015) Cerebellar associative sensory learning defects in five mouse autism models. eLife 4:e06085. CrossRef Medline

Koekkoek SK, Hulscher HC, Dortland BR, Hensbroek RA, Elgersma Y, Ruigrok TJ, De Zeeuw CI (2003) Cerebellar LTD and learningdependent timing of conditioned eyelid responses. Science 301:17361739. CrossRef Medline

Konno K, Matsuda K, Nakamoto C, Uchigashima M, Miyazaki T, Yamasaki
M, Sakimura K, Yuzaki M, Watanabe M (2014) Enriched expression of GluD1 in higher brain regions and its involvement in parallel fiberinterneuron synapse formation in the cerebellum. J Neurosci 34:74127424. CrossRef Medline

Kusnoor SV, Parris J, Muly EC, Morgan JI, Deutch AY (2010) Extracerebellar role for Cerebellin1: modulation of dendritic spine density and synapses in striatal medium spiny neurons. J Comp Neurol 518:2525-2537. CrossRef Medline

Lalonde R, Strazielle C (2003) The effects of cerebellar damage on maze learning in animals. Cerebellum 2:300-309. CrossRef Medline

Lomeli H, Sprengel R, Laurie DJ, Köhr G, Herb A, Seeburg PH, Wisden W (1993) The rat delta- 1 and delta-2 subunits extend the excitatory amino acid receptor family. FEBS Lett 315:318-322. CrossRef Medline

Lorincz A, Nusser Z (2008) Specificity of immunoreactions: the importance of testing specificity in each method. J Neurosci 28:9083-9086. CrossRef Medline

Maier A, Klopocki E, Horn D, Tzschach A, Holm T, Meyer R, Meyer T (2014) De novo partial deletion in GRID2 presenting with complicated spastic paraplegia. Muscle Nerve 49:289-292. CrossRef Medline

Maren S, Holt WG (2004) Hippocampus and Pavlovian fear conditioning in rats: muscimol infusions into the ventral, but not dorsal, hippocampus impair the acquisition of conditional freezing to an auditory conditional stimulus. Behav Neurosci 118:97-110. CrossRef Medline

Matsuda K, Miura E, Miyazaki T, Kakegawa W, Emi K, Narumi S, Fukazawa Y, Ito-Ishida A, Kondo T, Shigemoto R, Watanabe M, Yuzaki M (2010) Cbln1 is a ligand for an orphan glutamate receptor delta2, a bidirectional synapse organizer. Science 328:363-368. CrossRef Medline

Miura E, Iijima T, Yuzaki M, Watanabe M (2006) Distinct expression of Cbln family mRNAs in developing and adult mouse brains. Eur J Neurosci 24:750-760. CrossRef Medline

Miura E, Matsuda K, Morgan JI, Yuzaki M, Watanabe M (2009) Cbln1 accumulates and colocalizes with Cbln 3 and GluRdelta2 at parallel fiber-Purkinje cell synapses in the mouse cerebellum. Eur J Neurosci 29:693-706. CrossRef Medline

Miyazaki T, Fukaya M, Shimizu H, Watanabe M (2003) Subtype switching of vesicular glutamate transporters at parallel fibre-Purkinje cell synapses in developing mouse cerebellum. Eur J Neurosci 17:2563-2572. CrossRef Medline

Miyazaki T, Yamasaki M, Hashimoto K, Yamazaki M, Abe M, Usui H, Kano M, Sakimura K, Watanabe M (2012) Cav2.1 in cerebellar Purkinje cells regulates competitive excitatory synaptic wiring, cell survival, and cerebellar biochemical compartmentalization. J Neurosci 32:1311-1328. CrossRef Medline

Mugnaini E, Morgan JI (1987) The neuropeptide cerebellin is a marker for two similar neuronal circuits in rat brain. Proc Natl Acad Sci U S A 84: 8692-8696. CrossRef Medline

Oda S, Funato H, Sato F, Adachi-Akahane S, Ito M, Takase K, Kuroda M (2014) A subset of thalamocortical projections to the retrosplenial cortex possesses two vesicular glutamate transporter isoforms, VGluT1 and VGluT2, in axon terminals and somata. J Comp Neurol 522:2089-2106. CrossRef Medline

Ohmae S, Medina JF (2015) Climbing fibers encode a temporal-difference prediction error during cerebellar learning in mice. Nat Neurosci 18 : 1798-1803. CrossRef Medline

Pinto D et al. (2014) Convergence of genes and cellular pathways dysregulated in autism spectrum disorders. Am J Hum Genet 94:677-694. CrossRef Medline

Reeber SL, Otis TS, Sillitoe RV (2013) New roles for the cerebellum in health and disease. Front Syst Neurosci 7:83. CrossRef Medline

Rochefort C, Arabo A, André M, Poucet B, Save E, Rondi-Reig L (2011) Cerebellum shapes hippocampal spatial code. Science 334:385-389. CrossRef Medline

Sacchetti B, Scelfo B, Tempia F, Strata P (2004) Long-term synaptic changes induced in the cerebellar cortex by fear conditioning. Neuron 42:973982. CrossRef Medline

Slemmon JR, Blacher R, Danho W, Hempstead JL, Morgan JI (1984) Isolation and sequencing of two cerebellum-specific peptides. Proc Natl Acad Sci U S A 81:6866-6870. CrossRef Medline

Stoodley CJ, Schmahmann JD (2010) Evidence for topographic organization in the cerebellum of motor control versus cognitive and affective processing. Cortex 46:831-844. CrossRef Medline 
Strata P, Scelfo B, Sacchetti B (2011) Involvement of cerebellum in emotional behavior. Physiol Res 60:S39-S48. Medline

Tsai PT, Hull C, Chu Y, Greene-Colozzi E, Sadowski AR, Leech JM, Steinberg J, Crawley JN, Regehr WG, Sahin M (2012) Autistic-like behaviour and cerebellar dysfunction in Purkinje cell Tscl mutant mice. Nature 488: 647-651. CrossRef Medline

Utine GE, Haliloğlu G, Salanci B, Çetinkaya A, Kiper PÖ, Alanay Y, Aktas D, Boduroğlu K, Alikaşifoğlu M (2013) A homozygous deletion in GRID2 causes a human phenotype with cerebellar ataxia and atrophy. J Child Neurol 28:926-932. CrossRef Medline

Wallace KJ, Rosen JB (2000) Predator odor as an unconditioned fear stimulus in rats: Elicitation of freezing by trimethylthiazoline, a component of fox feces. Behav Neurosci 114:912-922. CrossRef Medline

Watanabe M, Fukaya M, Sakimura K, Manabe T, Mishina M, Inoue Y (1998) Selective scarcity of NMDA receptor channel subunits in the stratum lucidum (mossy fibre-recipient layer) of the mouse hippocampal CA3 subfield. Eur J Neurosci 10:478-487. CrossRef Medline
Wei P, Smeyne RJ, Bao D, Parris J, Morgan JI (2007) Mapping of Cbln1-like immunoreactivity in adult and developing mouse brain and its localization to the endolysosomal compartment of neurons. Eur J Neurosci 26: 2962-2978. CrossRef Medline

Wulff P, Schonewille M, Renzi M, Viltono L, Sassoè-Pognetto M, Badura A, Gao Z, Hoebeek FE, van Dorp S, Wisden W, Farrant M, De Zeeuw CI (2009) Synaptic inhibition of Purkinje cells mediates consolidation of vestibulo-cerebellar motor learning. Nat Neurosci 12:10421049. CrossRef Medline

Yamasaki M, Matsui M, Watanabe M. (2010) Preferential localization of muscarinic M1 receptor on dendritic shaft and spine of cortical pyramidal cells and its anatomical evidence for volume transmission. J Neurosci 30:4408-4418.

Zeng H, Chattarji S, Barbarosie M, Rondi-Reig L, Philpot BD, Miyakawa T, Bear MF, Tonegawa S (2001) Forebrain-specific calcineurin knock-out selectively impairs bidirectional synaptic plasticity and working/episodiclike memory. Cell 107:617-629. CrossRef Medline 